Louisiana State University

LSU Digital Commons

Faculty Publications

Department of Chemistry

$1-1-2015$

\title{
Synthesis, spectroscopic, and in vitro investigations of 2,6-diiodo- BODIPYs with PDT and bioimaging applications
}

\author{
Jaime H. Gibbs \\ Louisiana State University \\ Zehua Zhou \\ Louisiana State University \\ David Kessel \\ Wayne State University School of Medicine \\ Frank R. Fronczek \\ Louisiana State University \\ Svetlana Pakhomova \\ Louisiana State University
}

See next page for additional authors

Follow this and additional works at: https://digitalcommons.Isu.edu/chemistry_pubs

\section{Recommended Citation}

Gibbs, J., Zhou, Z., Kessel, D., Fronczek, F., Pakhomova, S., \& Vicente, M. (2015). Synthesis, spectroscopic, and in vitro investigations of 2,6-diiodo-BODIPYs with PDT and bioimaging applications. Journal of Photochemistry and Photobiology B: Biology, 145, 35-47. https://doi.org/10.1016/

j.jphotobiol.2015.02.006

This Article is brought to you for free and open access by the Department of Chemistry at LSU Digital Commons. It has been accepted for inclusion in Faculty Publications by an authorized administrator of LSU Digital Commons.

For more information, please contact ir@lsu.edu. 
Authors

Jaime H. Gibbs, Zehua Zhou, David Kessel, Frank R. Fronczek, Svetlana Pakhomova, and M. Graça H. Vicente 
Louisiana State University

LSU Digital Commons

Faculty Publications

Department of Biological Sciences

$1-1-2015$

\title{
Synthesis, spectroscopic, and in vitro investigations of 2,6-diiodo- BODIPYs with PDT and bioimaging applications
}

\author{
Jaime H. Gibbs \\ Louisiana State University \\ Zehua Zhou \\ Louisiana State University \\ David Kessel \\ Wayne State University School of Medicine \\ Frank R. Fronczek \\ Louisiana State University \\ Svetlana Pakhomova \\ Louisiana State University
}

See next page for additional authors

Follow this and additional works at: https://digitalcommons.Isu.edu/biosci_pubs

\section{Recommended Citation}

Gibbs, J., Zhou, Z., Kessel, D., Fronczek, F., Pakhomova, S., \& Vicente, M. (2015). Synthesis, spectroscopic, and in vitro investigations of 2,6-diiodo-BODIPYs with PDT and bioimaging applications. Journal of Photochemistry and Photobiology B: Biology, 145, 35-47. https://doi.org/10.1016/

j.jphotobiol.2015.02.006

This Article is brought to you for free and open access by the Department of Biological Sciences at LSU Digital Commons. It has been accepted for inclusion in Faculty Publications by an authorized administrator of LSU Digital Commons. For more information, please contact ir@lsu.edu. 
Authors

Jaime H. Gibbs, Zehua Zhou, David Kessel, Frank R. Fronczek, Svetlana Pakhomova, and M. Graça H. Vicente 


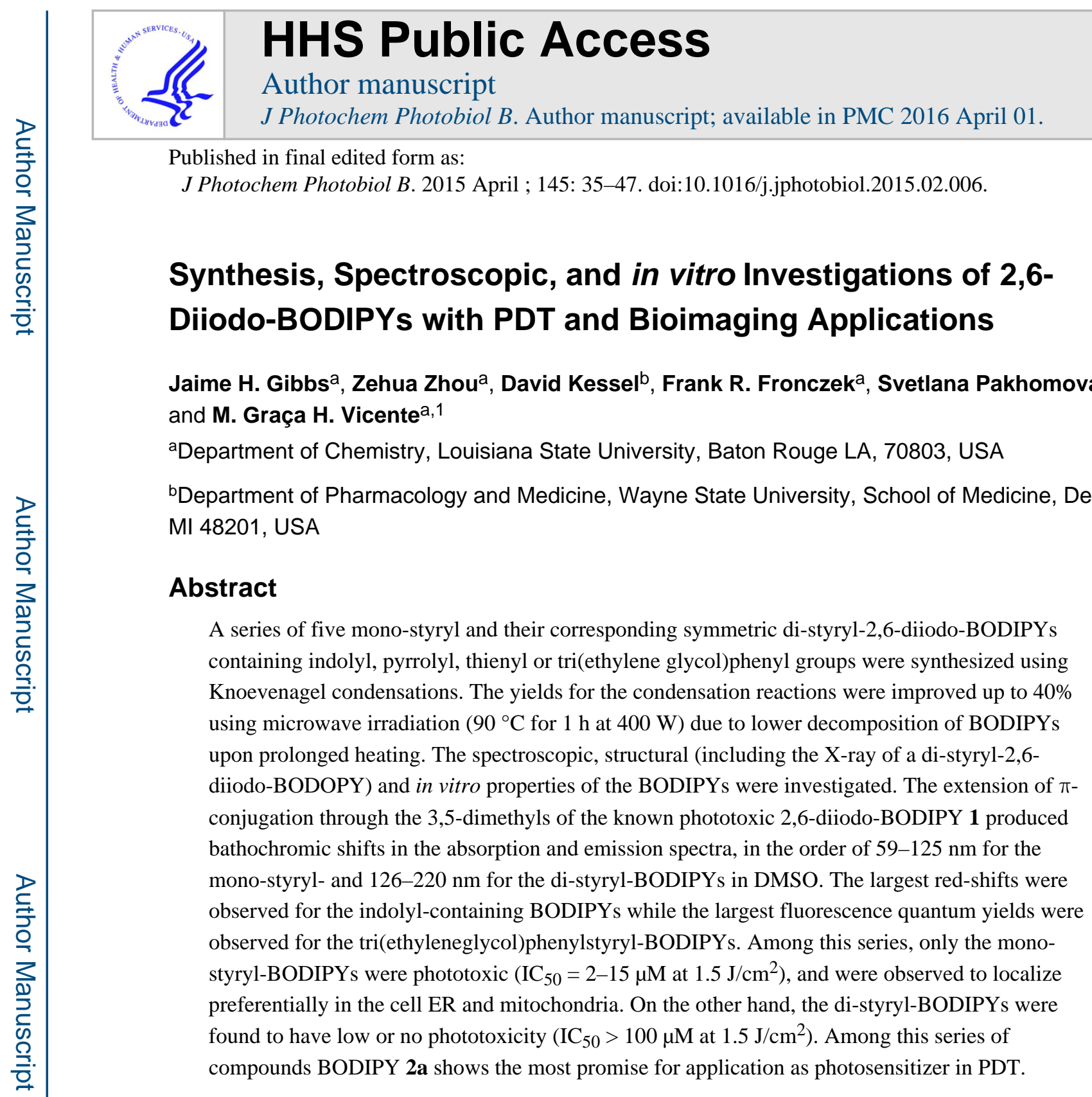

Keywords

BODIPY; PDT; fluorescence; cytotoxicity; cellular uptake

\section{Introduction}

The investigation of BODIPY (difluoro boron dipyrromethene)-based bioimaging agents has been an active area of research in recent decades, that has produced a multitude of

(C) 2015 Published by Elsevier B.V.

${ }^{1}$ Corresponding author. Phone: (225) 578 7405, Fax: (225) 578 3458, vicente@1su.edu.

Publisher's Disclaimer: This is a PDF file of an unedited manuscript that has been accepted for publication. As a service to our customers we are providing this early version of the manuscript. The manuscript will undergo copyediting, typesetting, and review of the resulting proof before it is published in its final citable form. Please note that during the production process errors may be discovered which could affect the content, and all legal disclaimers that apply to the journal pertain. 
fluorescent dyes with a variety of purposes including use as labels for biomolecules such as DNA, peptides, and lipids[1-4], as well as for applications as enzyme substrate fluorescent tags[5,6], as environmental indicators ( $\mathrm{pH}$ and ion sensors)[7-10], and as cellular stains [11]. Despite their extensive investigation, only a few studies have evaluated BODIPYs for applications as photodynamic therapy (PDT) photosensitizers and as radioimaging agents, particularly for positron emission tomography (PET) and single photon emission computed tomography (SPECT). PDT is an effective and FDA-approved treatment for several forms of cancer and the age-related macular degeneration, using a porphyrin derivative as the photosensitizer. PDT is a tri-modal cancer therapy that combines a photosensitizer, light, and oxygen to generate reactive oxygen species (ROS), including singlet oxygen $\left({ }^{1} \mathrm{O}_{2}\right)$, that cause cell death $[12,13]$. PDT has many benefits over other therapies, including limited long-term side effects, relatively short treatment times, and the option for multiple treatments to be administered, due to its non-invasive nature and limited area of exposure [14-16]. Effective photosensitizers possess properties favoring singlet oxygen generation, including high quantum yields of photosensitizer triplet state $\left(\Phi_{\mathrm{T}}>0.4\right)$, long triplet state lifetimes $\left(\tau_{\mathrm{T}} \sim 1 \mu \mathrm{s}\right)$ and energy $\left(\mathrm{E}_{\mathrm{T}} \geq 95 \mathrm{~kJ} \mathrm{~mol}^{-1}\right)$, for efficient energy transfer to triplet molecular oxygen. In addition, low dark cytotoxicity, high photostability, and high absorption coefficients in the near-IR range $(630 \mathrm{~nm}-800 \mathrm{~nm})$ are desirable, since they allow for the use of long wavelength light with reduced tissue autofluorescence and scattering, and increased tissue penetration [17]. Current PDT anticancer agent Photofrin ${ }^{\circledR}$ (Pinnacle Biologics, Inc.) is FDA-approved for the treatment of melanoma, esophageal, digestive tract, genitourinary tract, and lung cancers. Although effective, Photofrin ${ }^{\circledR}$ has some drawbacks in that it absorbs only weakly in the red region of the spectrum, and is a mixture of compounds (porphyrin monomers and oligomers) with prolonged retention times in tissues, which causes patient photosensitivity for several weeks post-PDT [18]. In order to broaden the scope of PDT, development of photosensitizers with increased extinction coefficient within the therapeutic window, and high photodynamic activity are being actively explored.

BODIPY dyes have recently been shown to have potential application as PDT photosensitizers $[19,20]$. Their remarkable photophysical properties, including high extinction coefficients, easily tunable absorption and emission profiles, high stability and solubility, as well as their known ability to permeate cells, make them suitable for exploration as PDT agents [21,22]. It has been shown that some BODIPYs bearing heavy atoms, such as iodine or bromine, display cytotoxic properties when exposed to light while others remain non-toxic [23-29]. The effects of the "spin-orbit couplings" of heavy atoms favor intersystem crossing from the excited singlet to the triplet state needed for singlet oxygen generation [30-32]. Studies have shown that incorporation of iodines at the 2,6positions of BODIPYs leads to enhanced intersystem crossing, whereas addition at the 3,5positions promotes fluorescence [30]. In addition, phototoxicity depends on the substituents on the 2,6-diiodo-BODIPYs, and is favored by electron-donating 8-aryl groups [23-26].

The discovery of non-toxic halogenated BODIPYs, specifically those bearing iodines and fluorines, can lead to the development of multi-mode bioimaging agents for PET and SPECT, in addition to fluorescence imaging, with the incorporation of radioisotopes of iodine and fluorine. Nuclear imaging allows for the translation of the pathophysiological status of the tissues being imaged without interference. PET and SPECT are non-invasive 
3D nuclear imaging techniques that allow for the mapping of a radiotracer's uptake in vivo [33]. PET most commonly utilizes ${ }^{18} \mathrm{~F}$-labeled radiopharmaceuticals $\left(\mathrm{t}_{1 / 2}=109\right.$ minutes) and a ${ }^{18} \mathrm{~F}$-labelled glucose derivative has shown to have great success in clinical imaging. Only a handful of reports have been published detailing the evaluation of ${ }^{18} \mathrm{~F}$-bearing BODIPYs for PET/fluorescence dual modality imaging [34-36]. The ${ }^{120} \mathrm{I}$ and ${ }^{124} \mathrm{I}$ radioisotopes ( $\mathrm{t}_{1 / 2}=81$ minutes and 4.18 days, respectively) also possess favorable PET qualities [33,37]. However, their low positron emission abundance, high positron energies, and lengthy synthetic protocols have hindered their widespread application in routine PET imaging. On the other hand, ${ }^{123} \mathrm{I}$ and ${ }^{131} \mathrm{I}\left(\mathrm{t}_{1 / 2}=13.2\right.$ hours and 8.05 days, respectively $)$ have found significant importance as SPECT radiotracers for long term in vitro studies and radioimmunoassays. Many SPECT radiotracers are FDA-approved and currently used in clinical diagnostics. SPECT imaging is highly favored due to its ability to image endogenous peptides and antibodies, and due to the relatively long half-life of these isotopes, provides a means for measuring the slow kinetic processes of these ligands. To date, no studies on the synthesis and evaluation of radioiodine-labelled BODIPYs as SPECT radiotracers have been published. Ideal radiopharmaceuticals should possess characteristics that provide detectable diagnostic particles with minimal biological effect to cells or tissues, including relatively short half-life, suitable radionucleotide emissions of desired energy, high target uptake with high target-to-normal tissue ratio, efficient clearance from blood and non-target tissues while persisting in target for effective image contrast, and be inexpensive and easy to produce.

We have recently reported the synthesis and cytotoxicity properties of near-IR mono-and diindolylstyryl-BODIPYs [38], and a series of 2,6-diiodo-BODIPYs [26]. Among these, the mono- indolylstyryl-BODIPYs showed high uptake by HEp2 cells with no detectable cytotoxicity in the absence or presense of light, while the 8-(3,5-dimethyoxyphenyl)-2,6diiodo-1,3,5,7-tetramethyl-BODIPY (1) showed high phototoxicity $\left(\mathrm{IC}_{50}=4 \mu \mathrm{M}\right.$ at 1.5 $\mathrm{J} / \mathrm{cm}^{2}$ ) but remained non-toxic in the dark $\left(\mathrm{IC}_{50}>400 \mu \mathrm{M}\right)$. Herein we report the synthesis of near-IR derivatives of BODIPY 1 by extension of the $\pi$-conjugation via Knoevenagel condensations on the 3,5-methyl groups, and the evaluation of their photophysical and in vitro properties. Our results show that the mono-styryl-2,6-diiodo-BODIPYs show promise for application as PDT photosensitizers, while the di-styryl-2,6-diiodo-BODIPYs display low cytotoxicity and may find applications as multi-mode near-IR fluorescent, PET and/or SPECT imaging probes.

\section{Materials and Methods}

\subsection{Synthesis and characterization}

2.1.1. General-Reagents and solvents were acquired from Sigma Aldrich and used without further purification. Reactions were monitored by TLC using $0.2 \mathrm{~mm}$ silica plates with UV indicator (UV254). Column chromatography was executed using Sorbent Technologies $60 \dot{A}$ silica gel (230-400 mesh) or Merck neutral aluminum oxide (70-230 mesh). Merck TLC silica gel 60 glass plates were use for preparative thin layer chromatography. All ${ }^{1} \mathrm{H}$ NMR and ${ }^{13} \mathrm{C}$ NMR spectra were obtained using a Bruker AV-500, DPX-400, AV-400, or DPX-250 spectrometer $\left(500 \mathrm{MHz}, 400 \mathrm{MHz}\right.$ or $250 \mathrm{MHz}$ for ${ }^{1} \mathrm{H}, 100$ 
$\mathrm{MHz}$ for ${ }^{13} \mathrm{C}$ ) with samples dissolved in deuterated chloroform, acetone, or DMSO using trimethylsilane as an internal indicator. Chemical shifts $(\delta)$ are conveyed in ppm with $\mathrm{CDCl}_{3}$ $\left({ }^{1} \mathrm{H}: 7.27 \mathrm{ppm} ;{ }^{13} \mathrm{C}: 77.16 \mathrm{ppm}\right)$, acetone-d6 $\left({ }^{1} \mathrm{H}: 2.05 \mathrm{ppm} ;{ }^{13} \mathrm{C}: 29.84 \mathrm{ppm}\right)$, and DMSO$\mathrm{d}_{6}\left({ }^{1} \mathrm{H}: 2.50 \mathrm{ppm} ;{ }^{13} \mathrm{C}: 39.52 \mathrm{ppm}\right)$ used as references. Coupling constants $(\mathrm{J})$ are stated in Hertz (Hz). High resolution ESI mass spectra were obtained using an Agilent Technologies 6210 ESI-TOF Mass Spectrometer.

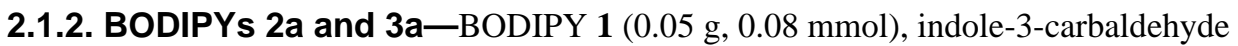
$(0.06 \mathrm{~g}, 0.4 \mathrm{mmol})$, and $\mathrm{AcOH}(0.4 \mathrm{~mL})$ were dissolved in dry toluene over $4 \AA$ molecular sieves $(20 \mu \mathrm{M})$. To this solution was added piperidine $(0.4 \mathrm{~mL})$ and the mixture was stirred under $400 \mathrm{~W}$ microwave radiation at $90^{\circ} \mathrm{C}$ for $1 \mathrm{~h}$. Upon cooling, the reaction was filtered to remove the sieves and the filtrate was quenched with water and extracted with $\mathrm{CH}_{2} \mathrm{Cl}_{2}$. The combined organic layers were dried over $\mathrm{Na}_{2} \mathrm{SO}_{4}$ and the solvent was removed under vacuum. The resulting residue was purified by silica column chromatography using $25 \%$ hexanes in $\mathrm{CH}_{2} \mathrm{Cl}_{2}$ (v/v) to $100 \% \mathrm{CH}_{2} \mathrm{Cl}_{2}$ to afford $0.0225 \mathrm{~g}$ of a blue solid, $\mathbf{2 a}$, in $38 \%$ yield and $0.028 \mathrm{~g}$ of a green solid, $\mathbf{3 a}$, in $40 \%$ yield. Data For $2 a$ : $\mathrm{mp}=175^{\circ} \mathrm{C}$ (decomposes); ${ }^{1} \mathrm{H}-\mathrm{NMR}\left(400 \mathrm{MHz}, \mathrm{CDCl}_{3}\right) \delta 8.53(\mathrm{~s}, 1 \mathrm{H}), 8.51-8.47(\mathrm{~d}, \mathrm{~J}=16.9,1 \mathrm{H})$, 8.13-8.11 (d, J = 7.3, 1H), 7.76-7.72 (d, J = 16.6, 1H), $7.56(\mathrm{~s}, 1 \mathrm{H}), 7.41-7.39(\mathrm{~d}, \mathrm{~J}=7.1$, $1 \mathrm{H}), 7.31-7.27(\mathrm{~m}, 2 \mathrm{H}), 6.60-6.58(\mathrm{t}, \mathrm{J}=2,1 \mathrm{H}), 6.46-6.45(\mathrm{~d}, \mathrm{~J}=2,2 \mathrm{H}), 3.19(\mathrm{~s}, 6 \mathrm{H}), 2.71$ (s, 3H), 1.64 (s, 3H), 1.57 (s, 3H); ${ }^{13} \mathrm{C}-\mathrm{NMR}(100 \mathrm{MHz}, \mathrm{CDCl} 3) \delta 161.82,154.95,152.16$, 146.56, 143.39, 138.51, 137.07, 136.84, 133.86, 127.27, 125.56, 123.25, 121.56, 120.68, 116.16, 115.07, 111.61, 106.21, 101.43, 69.55, 55.63, 53.80, 31.74, 29.28, 17.42, 16.72, 16.09; MS (ESI-TOF) $\mathrm{m} / \mathrm{z}$ calcd for $\mathrm{C}_{30} \mathrm{H}_{26} \mathrm{BF}_{2} \mathrm{I}_{2} \mathrm{~N}_{3} \mathrm{O}_{2}$ : 763.0175; Found: [M]+: 763.0186. Data for $3 a: \mathrm{mp}=195^{\circ} \mathrm{C}$ (decomposes); ${ }^{1} \mathrm{H}-\mathrm{NMR}(400 \mathrm{MHz}, \mathrm{CDCl} 3) \delta 8.53-8.48(\mathrm{~d}, \mathrm{~J}=$ $16.9,2 \mathrm{H}), 8.47$ (s, 2H), 8.21-8.19 (d, J = 7.3, 2H), 7.89-7.84 (d, J = 16.6, 2H), $7.56(\mathrm{~s}, 2 \mathrm{H})$, 7.43-7.41 (d, J = 7.1, 2H), 7.30-7.24 (m, 4H), 6.61-6.60 (t, J = 2, 1H), 6.51-6.50 (d, J = 2, $2 \mathrm{H}), 3.83$ (s, 6H), 2.64 (s, 3H), 1.65 (s, 6H); ${ }^{13} \mathrm{C}-\mathrm{NMR}\left(100 \mathrm{MHz}, \mathrm{CDCl}_{3}\right)$ 167.71, 161.75, 137.13, 132.92, 132.33, 130.91, 128.83, 127.14, 125.54, 125.03, 125.14, 121.64, 120.89, $116.45,115.65,111.55,106.64,101.45,55.64,17.27$; MS (ESI-TOF) $\mathrm{m} / z$ calcd for $\mathrm{C}_{39} \mathrm{H}_{31} \mathrm{BF}_{2} \mathrm{I}_{2} \mathrm{~N}_{4} \mathrm{O}_{2}$ : 890.0598; Found: [M]+: 890.0639.

2.1.3. BODIPYs 2b and 3b-BODIPY 1 ( $0.05 \mathrm{~g}, 0.08 \mathrm{mmol})$, aldehyde 8 ( $0.11 \mathrm{~g}, 0.4$ $\mathrm{mmol})$, and $\mathrm{AcOH}(0.4 \mathrm{~mL})$ were dissolved in dry toluene over $4 \AA$ molecular sieves (20 $\mu \mathrm{M})$. To this solution was added piperidine $(0.4 \mathrm{~mL})$ and the mixture was stirred under 400 $\mathrm{W}$ microwave radiation at $90^{\circ} \mathrm{C}$ for 60 minutes. Upon cooling, the reaction was filtered to remove the sieves and the filtrate was quenched with water and extracted with $\mathrm{CH}_{2} \mathrm{Cl}_{2}$. The combined organic layers were dried over $\mathrm{Na}_{2} \mathrm{SO}_{4}$ and the solvent was removed under vacuum. The resulting residue was purified by silica column chromatography using $25 \%$ ethyl acetate in $\mathrm{CH}_{2} \mathrm{Cl}_{2}$ (v/v) to afford $0.028 \mathrm{~g}$ of a blue solid, $\mathbf{2 b}$, in $40 \%$ yield and $0.030 \mathrm{~g}$ of a green solid, $\mathbf{3 b}$, in $26 \%$ yield. Data for $2 \boldsymbol{b}$ : $\mathrm{mp}=63-65^{\circ} \mathrm{C}$; $1 \mathrm{H}-\mathrm{NMR}(400 \mathrm{MHz}$, $\mathrm{CDCl} 3) \delta 8.15-8.11(\mathrm{~d}, \mathrm{~J}=16.9,1 \mathrm{H}), 7.60-7.57(\mathrm{~d}, \mathrm{~J}=8.6,2 \mathrm{H}), 7.57-7.52(\mathrm{~d}, \mathrm{~J}=16.6,1 \mathrm{H})$, 6.96-6.94 (d, J = 8.3, 1H), 6.60-6.59 (t, J = 2, 1H), 6.45-6.44 (d, J = 2, 2H), 4.20-4.18 (t, J = 4.5, 2H), 3.90-3.88 (t, J = 4.6, 2H), 3.83-3.80 (s, 3H), 3.76-3.71 (m, 2H), 3.69-3.66 (m, 4H), 3.58-3.56 (t, J = 4, 2H), $3.41(\mathrm{~s}, 3 \mathrm{H}), 2.70(\mathrm{~s}, 3 \mathrm{H}), 1.64(\mathrm{~s}, 3 \mathrm{H}), 1.59(\mathrm{~s}, 3 \mathrm{H}) ;{ }^{13} \mathrm{C}-\mathrm{NMR}(100$ $\mathrm{MHz}, \mathrm{CDCl} 3) \delta 161.89,159.96,156.72,150.73,146.17,144.86,139.64,139.04,136.57$, 
131.97, 131.51, 129.63, 129.15, 116.59, 114.87, 106.02, 101.46, 85.98, 82.19, 71.95, 70.89, 70.67, 70.59, 69.68, 67.55, 59.06, 55.63, 17.31, 16.87, 16.17; MS (ESI-TOF) $\mathrm{m} / \mathrm{z}$ calcd for $\mathrm{C}_{3} 5 \mathrm{H}_{3} 9 \mathrm{BF}_{2} \mathrm{I}_{2} \mathrm{~N}_{2} \mathrm{NaO}_{6}$ : 909.0856; Found: [M+Na]+: 909.0847. Data for $3 \boldsymbol{b}: \mathrm{mp}=131-$ $134^{\circ} \mathrm{C}$; 1H-NMR (400 MHz, CDCl3) 8 8.16-8.12 (d, J = 16.6, 2H), 7.61-7.57 (d, J = 8.6, $4 \mathrm{H}), 7.59-7.57(\mathrm{~d}, \mathrm{~J}=16.6,2 \mathrm{H}), 6.98-6.96(\mathrm{~d}, \mathrm{~J}=8.6,4 \mathrm{H}), 6.61-6.60(\mathrm{t}, \mathrm{J}=2,1 \mathrm{H})$, 6.46-6.45 (d, J = 2, 2H), 4.21-4.18 (t, J = 4.5, 4H), 3.91-3.88 (t, J = 4.6, 4H), $3.82(\mathrm{~s}, 6 \mathrm{H})$, 3.78-7.75 (m, 4H), 3.72-3.66 (m, 8H), 3.58-3.55 (t, J = 4, 4H), $3.39(\mathrm{~s}, 6 \mathrm{H}), 1.62(\mathrm{~s}$, $6 \mathrm{H}) ;{ }^{13} \mathrm{C}-\mathrm{NMR}(100 \mathrm{MHz}, \mathrm{CDCl} 3) \delta 161.86,159.97,150.53,145.68,139.12,138.04$, 136.86, 132.52, 129.71, 129.25, 128.82, 116.76, 114.97, 114.30, 106.31, 101.45, 71.94, $70.88,70.67,70.59,69.69,67.56,59.07,55.63,17.35$; MS (ESI-TOF) $\mathrm{m} / z$ calcd for $\mathrm{C}_{49} \mathrm{H}_{57} \mathrm{BF}_{2} \mathrm{I}_{2} \mathrm{~N}_{2} \mathrm{NaO}_{10}$ : 1159.2062; Found: [M+Na]+: 1159.2065 .

2.1.4. BODIPYs $2 \mathrm{c}$ and $3 \mathrm{c}-$ BODIPY $1(0.02 \mathrm{~g}, 0.03 \mathrm{mmol})$, thiophene-2carboxaldehyde $(0.0035 \mathrm{~g}, 0.03 \mathrm{mmol})$, and p-TsOH $(0.0025 \mathrm{~g})$ were dissolved in dry toluene over $4 \AA$ A molecular sieves $(5 \mu \mathrm{M})$. To this solution was added piperidine $(0.1 \mathrm{~mL})$ and the mixture was stirred at reflux for 4 hours. Upon cooling, the reaction was filtered to remove the sieves and the filtrate was quenched with water and extracted with $\mathrm{CH}_{2} \mathrm{Cl}_{2}$. The combined organic layers were dried over $\mathrm{Na}_{2} \mathrm{SO}_{4}$ and the solvent was removed under vacuum. The resulting residue was purified by careful silica preparatory plate chromatography using 1:1 DCM/hexanes (v/v) to afford $0.0048 \mathrm{~g}$ of a blue solid, $\mathbf{2 c}$, in $19 \%$ yield and $0.0064 \mathrm{~g}$ of a green solid, $3 \mathbf{c}$, in $25 \%$ yield. Data for $2 \mathrm{c}: \mathrm{mp}=165^{\circ} \mathrm{C}$ (decomposes); ${ }^{1} \mathrm{H}-\mathrm{NMR}\left(400 \mathrm{MHz}, \mathrm{CDCl}_{3}\right) \delta 8.29-8.26(\mathrm{~d}, \mathrm{~J}=16.2,1 \mathrm{H}), 7.47-7.44(\mathrm{~d}, \mathrm{~J}=$ $16.2,1 \mathrm{H}), 7.37-7.36(\mathrm{~d}, \mathrm{~J}=5.2,1 \mathrm{H}), 7.30-7.29(\mathrm{~d}, \mathrm{~J}=3.4,1 \mathrm{H}), 7.08-7.07(\mathrm{dxd}, \mathrm{J}=3.8,1.2$, $1 \mathrm{H}), 6.60-6.59(\mathrm{t}, \mathrm{J}=2,1 \mathrm{H}), 6.44-6.43(\mathrm{~d}, \mathrm{~J}=2,2 \mathrm{H}), 3.81(\mathrm{~s}, 3 \mathrm{H}), 2.70(\mathrm{~s}, 3 \mathrm{H}), 1.61(\mathrm{~s}$, $3 \mathrm{H}), 1.58$ (s, 3H); ${ }^{13} \mathrm{C}-\mathrm{NMR}(100 \mathrm{MHz}, \mathrm{CDCl} 3) \delta 161.91,157.51,149.64,145.80,145.78$, $142.57,139.77,136.49,131.81,128.85,128.06,127.30,117.99,105.98,101.47,55.62$, 17.23, 16.91, 16.23; MS (ESI-TOF) $\mathrm{m} / z$ calcd for $\mathrm{C}_{26} \mathrm{H}_{23} \mathrm{BF}_{2} \mathrm{I}_{2} \mathrm{~N}_{2} \mathrm{O}_{2} \mathrm{~S}$ : 729.9631; Found: $[\mathrm{M}]+:$ 729.9656. Data for $3 \mathrm{c}: \mathrm{mp}=170^{\circ} \mathrm{C}($ decomposes $) ;{ }^{1} \mathrm{H}-\mathrm{NMR}\left(500 \mathrm{MHz}, \mathrm{CDCl}_{3}\right) \delta$ 8.33-8.30 (d, J = 16.2, 2H), 7.53-7.50 (d, J = 16.5, 2H), 7.40-7.39 (d, J = 4.9, 2H), 7.33-7.32 $(\mathrm{d}, \mathrm{J}=3.4,2 \mathrm{H}), 7.10-7.08(\mathrm{dxd}, \mathrm{J}=4,2 \mathrm{H}), 6.61-6.60(\mathrm{t}, \mathrm{J}=2,1 \mathrm{H}), 6.46-6.45(\mathrm{~d}, \mathrm{~J}=2,2 \mathrm{H})$, 3.82 (s, 6H), $1.62(\mathrm{~s}, 6 \mathrm{H}) ;{ }^{13} \mathrm{C}-\mathrm{NMR}\left(100 \mathrm{MHz}, \mathrm{CDCl}_{3}\right) \delta 161.90,149.95,145.76,142.66$, 136.74, 132.97, 132.23, 129.01, 128.13, 127.55, 118.06, 113.93, 106.27, 101.51, 83.62, 55.64, 17.33; MS (ESI-TOF) $\mathrm{m} / z$ calcd for $\mathrm{C}_{31} \mathrm{H}_{25} \mathrm{BF}_{2} \mathrm{I}_{2} \mathrm{~N}_{2} \mathrm{O}_{2} \mathrm{~S}_{2}$ : 823.9508; Found: [M]+: 823.9512.

2.1.5. BODIPYs 2d and 3d-BODIPY $1(0.04 \mathrm{~g}, 0.063 \mathrm{mmol})$, 5-nitroindole-3carboxaldehyde $(0.06 \mathrm{~g}, 0.315 \mathrm{mmol})$, and $\mathrm{p}-\mathrm{TsOH}(0.005 \mathrm{~g})$ were dissolved in dry toluene $20 \mathrm{~mL}$. To this solution was added piperidine $(0.4 \mathrm{~mL})$ and the mixture was stirred under nitrogen at $60^{\circ} \mathrm{C}$ for 6.5 hours. Upon cooling, the reaction was quenched with water and extracted with $\mathrm{CH}_{2} \mathrm{Cl}_{2}$. The combined organic layers were dried over $\mathrm{Na}_{2} \mathrm{SO}_{4}$ and the solvent was removed under vacuum. The resulting residue was purified by silica column chromatography using $\mathrm{CH}_{2} \mathrm{Cl}_{2}$ to $10 \% \mathrm{EtOAc/} \mathrm{CH}_{2} \mathrm{Cl}_{2}$ (v/v) to afford $0.0095 \mathrm{~g}$ of a blue solid, $2 \mathbf{d}$, in $15 \%$ yield and $0.0136 \mathrm{~g}$ of a green solid, $\mathbf{3 d}$, in $22 \%$ yield. Data for $2 \mathrm{~d}: \mathrm{mp}=$ $140^{\circ} \mathrm{C}$ (decomposes); ${ }^{1} \mathrm{H}-\mathrm{NMR}\left(400 \mathrm{MHz}, \mathrm{CDCl}_{3}\right) \delta 9.07$ (s, $\left.1 \mathrm{H}\right), 8.82(\mathrm{~s}, 1 \mathrm{H}), 8.41-8.38$ $(\mathrm{d}, \mathrm{J}=16.8,1 \mathrm{H}), 8.21-8.20(\mathrm{~d}, \mathrm{~J}=8.9,1 \mathrm{H}), 7.80-7.77(\mathrm{~d}, \mathrm{~J}=16.8,2 \mathrm{H}), 7.74(\mathrm{~s}, 1 \mathrm{H})$, 
7.49-7.47 (d, J = 9.2, 1H), 6.63-6.62 (t, J = 2, 1H), 6.48-6.47 (d, J = 2, 2H), $3.84(\mathrm{~s}, 3 \mathrm{H})$, 2.76 (s, 3H), 2.20 (s, 3H), 1.67 (s, 3H); ${ }^{13} \mathrm{C}-\mathrm{NMR}(100 \mathrm{MHz}, \mathrm{CDCl} 3) \delta$ 161.92, 157.17, 154.77, 145.03, 142.92, 139.64, 136.55, 130.26, 128.84, 127.99, 127.22, 125.22, 118.72, 118.31, 118.14, 118.02, 117.78, 117.63, 111.57, 106.05, 101.48, 55.64, 17.23, 16.89, 16.19; MS (ESI-TOF) $\mathrm{m} / \mathrm{z}$ calcd for $\mathrm{C}_{30} \mathrm{H}_{25} \mathrm{BF}_{2} \mathrm{I}_{2} \mathrm{~N}_{4} \mathrm{O}_{4}$ : 808.0026; Found: [M]+: 808.0020. Data for3d: $\mathrm{mp}=170^{\circ} \mathrm{C}$ (decomposes); ${ }^{1} \mathrm{H}-\mathrm{NMR}\left(500 \mathrm{MHz}, \mathrm{DMSO}-\mathrm{d}_{6}\right) \delta 12.45(\mathrm{~s}, 2 \mathrm{H}), 8.91$ (s, $2 \mathrm{H}), 8.53-8.49(\mathrm{~d}, \mathrm{~J}=16.8,2 \mathrm{H}), 8.16(\mathrm{~s}, 2 \mathrm{H}), 8.09-8.06(\mathrm{~d}, \mathrm{~J}=8.9,2 \mathrm{H}), 7.79-7.76(\mathrm{~d}, \mathrm{~J}=$ $16.8,2 \mathrm{H}), 7.67-7.65(\mathrm{~d}, \mathrm{~J}=8.9,2 \mathrm{H}), 6.68(\mathrm{~s}, 3 \mathrm{H}), 3.80(\mathrm{~s}, 6 \mathrm{H}), 2.08(\mathrm{~s}, 6 \mathrm{H}) ;{ }^{13} \mathrm{C}-\mathrm{NMR}(100$ MHz, DMSO-d 6 ) $\delta 161.95,150.09,147.42,145.55,142.27,141.02,137.51,136.75,133.05$, 132.63, 132.15, 124.66, 118.29, 116.96, 116.49, 115.79, 113.45, 106.65, 56.09, 17.24; MS (ESI-TOF) $m / z$ calcd for $\mathrm{C}_{39} \mathrm{H}_{29} \mathrm{BF}_{2} \mathrm{I}_{2} \mathrm{~N}_{6} \mathrm{O}_{6}$ : 980.0299; Found: [M]+: 980.0327.

2.1.6. BODIPYs 2e and 3e-BODIPY 1 ( $0.04 \mathrm{~g}, 0.063 \mathrm{mmol})$, ethyl 4-formyl-3,5dimethylpyrrole-2-carboxylate $(0.061 \mathrm{~g}, 0.315 \mathrm{mmol})$, and p-TsOH $(0.005 \mathrm{~g})$ were dissolved in dry toluene $(20 \mathrm{~mL})$ over $4 \AA$ molecular sieves. To this solution was added piperidine $(0.4$ $\mathrm{mL}$ ) and the mixture was stirred under nitrogen at $60^{\circ} \mathrm{C}$ for 48 hours. Upon cooling, the reaction was filtered to remove the sieves and the filtrate was quenched with water and extracted with $\mathrm{CH}_{2} \mathrm{Cl}_{2}$. The combined organic layers were dried over $\mathrm{Na}_{2} \mathrm{SO}_{4}$ and the solvent was removed under vacuum. The resulting residue was purified by silica preparatory plate chromatography using $\mathrm{CH}_{2} \mathrm{Cl}_{2}$ to $5 \% \mathrm{EtOAc} / \mathrm{CH}_{2} \mathrm{Cl}_{2}$ (v/v) to afford $0.0098 \mathrm{~g}$ of a blue solid, $2 \mathbf{e}$, in $19 \%$ yield and $0.024 \mathrm{~g}$ of a green solid, $\mathbf{3 e}$, in $39 \%$ yield. Data for $2 \boldsymbol{e}: \mathrm{mp}=$ $160^{\circ} \mathrm{C}$ (decomposes); ${ }^{1} \mathrm{H}-\mathrm{NMR}\left(500 \mathrm{MHz}, \mathrm{CDCl}_{3}\right.$ ) $\delta 8.90$ (br s, $1 \mathrm{H}$ ), 8.25-8.22 (d, J = 16.9, $1 \mathrm{H}), 7.39-7.36(\mathrm{~d}, \mathrm{~J}=17.1,2 \mathrm{H}), 6.59-6.58(\mathrm{t}, \mathrm{J}=2,1 \mathrm{H}), 6.44-6.43(\mathrm{~d}, \mathrm{~J}=2,2 \mathrm{H}), 4.37-4.33$ $(\mathrm{q}, \mathrm{J}=6.9,2 \mathrm{H}), 3.81(\mathrm{~s}, 3 \mathrm{H}), 2.65(\mathrm{~s}, 3 \mathrm{H}), 2.56(\mathrm{~s}, 3 \mathrm{H}), 2.54(\mathrm{~s}, 3 \mathrm{H}), 1.62(\mathrm{~s}, 3 \mathrm{H}), 1.56(\mathrm{~s}$, $3 \mathrm{H}), 1.41-1.38(\mathrm{t}, \mathrm{J}=7,3 \mathrm{H}) ;{ }^{13} \mathrm{C}-\mathrm{NMR}\left(100 \mathrm{MHz}, \mathrm{CDCl}_{3}\right) \delta 161.84,161.58,155.49$, $151.94,146.50,143.81,138.94,136.74,133.99,133.28,131.96,131.12,128.26,120.25$, 118.21, 116.16, 106.14, 101.40, 85.32, 81.84, 60.12, 55.61, 17.34, 16.75, 16.05, 14.52, 13.67, 11.47; MS (ESI-TOF) $\mathrm{m} / z$ calcd for $\mathrm{C}_{31} \mathrm{H}_{32} \mathrm{BF}_{2} \mathrm{I}_{2} \mathrm{~N}_{3} \mathrm{O}_{4}$ : 813.0543; Found: [M]+: 813.0538. Data for $3 \boldsymbol{e}: \mathrm{mp}=150^{\circ} \mathrm{C}$ (decomposes); ${ }^{1} \mathrm{H}-\mathrm{NMR}\left(500 \mathrm{MHz}\right.$, acetone-d $\left.\mathrm{d}_{6}\right) \delta 10.83$ (br s, 2H), 8.38-8.34 (d, J = 16.9, 2H), 7.59-7.54 (d, J = 16.9, 2H), 6.71 (s, 3H), 4.31-4.25 (q, $\mathrm{J}=6.9,4 \mathrm{H}), 3.89(\mathrm{~s}, 6 \mathrm{H}), 2.81(\mathrm{~s}, 3 \mathrm{H}), 2.77$ (s, 3H), $2.60(\mathrm{~s}, 3 \mathrm{H}), 1.65(\mathrm{~s}, 6 \mathrm{H}), 1.35-1.29(\mathrm{t}$, $\mathrm{J}=7,3 \mathrm{H}) ;{ }^{13} \mathrm{C}-\mathrm{NMR}\left(100 \mathrm{MHz}\right.$, acetone- $\left.\mathrm{d}_{6}\right) \delta 162.13,160.64,134.68,132.43,127.58$, 127.15, 119.71, 118.54, 115.85, 113.88, 106.28, 101.72, 76.34, 59.32, 55.20, 54.58, 48.21, $16.44,13.92,12.18,12.13,10.92$; MS (ESI-TOF) $\mathrm{m} / z$ calcd for $\mathrm{C}_{41} \mathrm{H}_{43} \mathrm{BF}_{2} \mathrm{I}_{2} \mathrm{~N}_{4} \mathrm{NaO}_{6}$ : 1013.1231; Found: [M+Na]+: 1013.1217.

2.1.7. Crystal data-Diffraction data were collected at $100 \mathrm{~K}$ on a Bruker Kappa Apex-II DUO diffractometer equipped with MoKa radiation $(\lambda=0.71073 \AA)$. Refinement was by full-matrix least squares using SHELXL, with $\mathrm{H}$ atoms in idealized positions. Compound $\mathbf{3 b}$ has four independent molecules and large displacement parameters for its polyether chains. Isotropic atoms with heavily restrained refinement was necessary in these regions, and some disorder in the polyethers could not be modeled. Crystal data: For 1: $\mathrm{C}_{21} \mathrm{H}_{21} \mathrm{BF}_{2} \mathrm{I}_{2} \mathrm{~N}_{2} \mathrm{O}_{2}$, monoclinic P21/c, a=7.0702(3), b=16.8644(7), c=18.4079(8) $\AA, \beta=92.838(2)^{\circ}, Z=4$, $\mathrm{T}=100 \mathrm{~K}, \theta_{\max }=40.34^{\circ}, \mathrm{R}=0.026$ for 11738 data with $\mathrm{I}>2 \sigma(\mathrm{I})$ (of 13815 unique), 277 parameters; For 3b: $\mathrm{C}_{49} \mathrm{H}_{57} \mathrm{BF}_{2} \mathrm{I}_{2} \mathrm{~N}_{2} \mathrm{O}_{10}$, triclinic $\mathrm{P} 1, \mathrm{a}=12.2712(5), \mathrm{b}=19.5190(8), \mathrm{c}=$ 
$22.4285(8) \AA, a=106.006(2), \beta=101.516(2), \gamma=104.576(2)^{\circ}, Z=4, T=100 \mathrm{~K}, \theta_{\max }=$ $30.11^{\circ}, \mathrm{R}=0.060$ for 30040 data with $\mathrm{I}>2 \sigma(\mathrm{I})$ (of 48144 unique), 1953 parameters, 2097 restraints. Cambridge Structural Database deposition numbers for the structures are CCDC 983490-983491. Copies if the data can be obtained, free of charge, on application to CCDC, 12 Union Road, Cambridge, CB2 1EZ, UK, (fax: +44-(0)1223-336033 or deposit@ccdc.cam.ac.uk).

2.1.8. Absorption and Fluorescence Spectroscopy-The spectroscopic properties of BODIPYs 1, 2a-e, and 3a-e were determined on solutions prepared by dissolving crystalline compound in dichloromethane, THF, or DMSO. Stock solutions $\left(5 \times 10^{-5} \mathrm{M}\right)$ were prepared and diluted to appropriate concentrations for collection of absorbance and emission spectra. Absorption spectra were obtained on a Varian Cary 50 Bio UV/VIS Spectrophotometer. Measurements obtained for determining optical density were taken from solutions with concentrations between $1.2 \times 10^{-5}$ and $5 \times 10^{-5} \mathrm{M}$ so that $\lambda$ max was between 0.5 and 1.0. Fluorescence measurements were recorded on solutions with concentrations between $1.2 \times 10^{-6}$ and $2.5 \times 10^{-5} \mathrm{M}$ to attain an optical density at the excitation wavelength between 0.04 and 0.06 to minimize intermolecular reabsorption and inner-filter effects. Compounds were excited at $485 \mathrm{~nm}$ for $\mathbf{1}, 530 \mathrm{~nm}$ for $\mathbf{2 a}, \mathbf{2 c}, \mathbf{2 d}$, and $\mathbf{2 e}, 535 \mathrm{~nm}$ for $\mathbf{2 b}, 660$ $\mathrm{nm}$ for 3a, $580 \mathrm{~nm}$ for $\mathbf{3 b}, 600 \mathrm{~nm}$ for $\mathbf{3 c}, 635 \mathrm{~nm}$ for 3d and $630 \mathrm{~nm}$ for 3e. Emission spectra were acquired on a PTI QuantaMaster4/2006SE spectrofluorometer with the slit width set at $3 \mathrm{~nm}$ for dichloromethane and THF and $5 \mathrm{~nm}$ for DMSO. Rhodamine $6 \mathrm{G}$ and methylene blue were used as standards in calculating the fluorescence quantum yields $\left(\Phi_{\mathrm{f}}=\right.$ 0.95 in ethanol and $\Phi_{\mathrm{f}}=0.03$ in methanol, respectively). All measurements, both absorbance and emission, were acquired within $4 \mathrm{~h}$ of solution preparation at room temperature (23-25 ${ }^{\circ} \mathrm{C}$ ), using a $10 \mathrm{~mm}$ path length quartz spectrophotometric cell.

The dark and photostability of all BODIPYs were assessed by measuring the change in fluorescence when excited at a compound specific wavelength ( $485 \mathrm{~nm}$ for 1, $530 \mathrm{~nm}$ for 2a, 2c, 2d, and $\mathbf{2 e}, 590 \mathrm{~nm}$ for $\mathbf{3 a}, 535 \mathrm{~nm}$ for $\mathbf{2 b}, 580 \mathrm{~nm}$ for $\mathbf{3 b}, 600 \mathrm{~nm}$ for $\mathbf{3 c}$ and $\mathbf{3 e}$, and 610 $\mathrm{nm}$ for $\mathbf{3 d}$ ). Solutions of $25 \mu \mathrm{M}$ BODIPY were made by dissolving crystalline BODIPY in DMSO and were used immediately. For dark studies, the vials containing BODIPY solutions were covered in aluminum foil to minimize light exposure. To assess potential photo-induced decomposition, the compounds were exposed to ambient light, by keeping the BODIPYs in $20 \mathrm{~mL}$ scintillation vials on the bench top under $32 \mathrm{~W}$ light from Sylvania OCTRON®/ECO® $4100 \mathrm{~K}$ for a period up to $24 \mathrm{~h}$.

\subsection{Cellular studies}

2.2.1. General-All reagents and tissue culture media were purchased from Invitrogen. The human carcinoma HEp2 and murine hepatoma 1c1c7 cells used for the studies were purchased from ATCC and were sustained at $37^{\circ} \mathrm{C}$ and $5 \% \mathrm{CO}_{2}$ in a 50:50 mixture of DMEM:AMEM augmented with 10\% FBS and $1 \%$ antibiotic (Penicillin-streptomycin). Working BODIPY stock solutions of $32 \mathrm{mM}$ BODIPY was prepared by dissolving the compound with sonication in 96\% DMSO and 4\% Cremophor EL. 
2.2.2. Time-dependent cellular uptake-The HEp2 cells were grown overnight in a Costar 96-well plate plated at 15,000 cells per well. The $32 \mathrm{mM}$ stock solution was diluted to a $10 \mu \mathrm{M}$ BODIPY solution through the addition of medium containing 5\% FBS and $1 \%$ antibiotic to a $400 \mu \mathrm{M}$ stock solution. The cells were exposed to the BODIPY in medium solution at $100 \mu \mathrm{L} /$ well at time intervals of $0,1,2,4,8$, and 24 hours. At the termination of the treatment, the loading medium was removed and the cells were washed with 1X PBS, and solubilized by adding $0.25 \%$ Triton X-100 in 1X PBS. Quantification of the cells was conducted using the CyQuant Cell Proliferation Assay (Life Technologies). BODIPY concentration was determined by reading fluorescence at $355 / 670 \mathrm{~nm}$ or $410 / 700 \mathrm{~nm}$ with a FluoStar Optima micro-plate reader (BMG LRBTEH). Cellular uptake is expressed in $\mathrm{nM}$ compound/cell.

2.2.3. Dark Cytotoxicity-The HEp2 cells were placed in a 96-well plate as above and allowed to incubate overnight. Following incubation, the cells were exposed to increasing concentrations of BODIPY, from $0 \mu \mathrm{M}$ up to $400 \mu \mathrm{M}$, and then incubated at $37^{\circ} \mathrm{C}$. After 24 hour incubation, the loading media containing compound was removed by washing the cells with 1X PBS. The media was replaced with media containing $20 \%$ Cell Titer Blue and the cells were incubated at $37^{\circ} \mathrm{C}$ for a subsequent 4 hours. Cell viability was determined by reading fluorescence at 570/615 nm with a FluoStar Optima micro-plate reader. The dark toxicity is expressed in terms of the percentage of viable cells.

2.2.4. Phototoxicity-The HEp2 cells were placed in 96-well plates as incubated as described above. Following incubation, the cells were exposed to increasing concentrations of BODIPY ( $0 \mu \mathrm{M}, 3.125 \mu \mathrm{M}, 6.25 \mu \mathrm{M}, 12.5 \mu \mathrm{M}, 25 \mu \mathrm{M}, 50 \mu \mathrm{M}$, and $100 \mu \mathrm{M})$ and then incubated for 24 hours at $37^{\circ} \mathrm{C}$. After the 24 hour treatment, the loading media was removed, the cells were washed with $1 \mathrm{X}$ PBS and refilled with fresh media. The cells were then exposed to a $600 \mathrm{~W}$ halogen lamp light source fitted with a water filter (Newport) and a beam turning mirror $200 \mathrm{~nm}-3 \mu \mathrm{m}$ (Newport) to generate an approximate light dose of 1.5 $\mathrm{J} / \mathrm{cm}^{2}$. After a $20 \mathrm{~min}$ exposure time, the cells were incubated for another $24 \mathrm{~h}$. Following incubation, the medium was removed and replaced with medium containing $20 \%$ of Cell Titer Blue and the cells were incubated for a subsequent 4 hours. Cell viability was determined by reading fluorescence at $570 / 615 \mathrm{~nm}$ with a FluoStar Optima micro-plate reader. The phototoxicity is expressed in terms of the percentage of viable cells.

2.2.5. Subcellular localization-HEp2 cells were plated in a 6-well plate and allowed to grow overnight. The cells were then exposed to $10 \mu \mathrm{M}$ of the compound at $37^{\circ} \mathrm{C}$ for more than 6 hours before adding the organelle tracer (Invitrogen). The working concentrations of organelle tracers were as following: LysoSensor Green $50 \mathrm{nM}$, MitoTracker Green $250 \mathrm{nM}$, ER Tracker Blue/white $100 \mathrm{nM}$, and BODIPY FL C5 Ceramide $50 \mathrm{nM}$. The organelle tracers were diluted in growing medium and the cells were incubated concurrently with the compound and the tracer for 30 minutes. After adding the tracer for 30 minutes, the loading medium is removed and cells were washed with $1 \mathrm{X}$ PBS three times. Images were acquired using a Leica DMRXA2 microscope with a water immersion objective and DAPI, GFP, Texas Red, and TRITC filter cubes (Chroma Technologies). 
2.2.6. ROS formation-For this study, murine hepatoma 1c1c7 cells (ATCC CRL-2026) were employed and maintained as previously described [39]. Murine hepatoma 1c1c7 cells were cultured on $22 \mathrm{~mm}$ glass coverslips. Formation of $\mathrm{OH}$ radical was assessed after incubation for $60 \mathrm{~min}$ at $37^{\circ} \mathrm{C}$ in medium containing $10 \mu \mathrm{M}$ concentrations of BODIPY 2a or 3a $+2 \mu \mathrm{M}$ of APF ([6-(4'-amino)phenoxy-3H-xanthen-3-on-9-yl]benzoic acid) or DADB (diethyl-3-3'-(9,10-anthracenediyl)bis acrylate). The medium was then replaced and the cells were irradiated. The light source was a $600 \mathrm{~W}$ quartz-halogen lamp with IR radiation attenuated by a $10 \mathrm{~cm}$ layer of water and further limited by interference filters $( \pm 10 \mathrm{~nm})$. The wavelengths employed were $630 \mathrm{~nm}(\mathbf{2 a})$ or $725 \mathrm{~nm}(\mathbf{3 a})$ at a light dose of $90 \mathrm{~mJ} / \mathrm{cm}^{2}$. Fluorescence of APF was detected by fluorescence microscopy using $450 \mathrm{~nm}$ excitation and measuring emission at $525 \mathrm{~nm}$. The signal increases as a function of $\bullet \mathrm{OH}$ formation. In contrast, DADB fluorescence is decreased when the probe interacts with ${ }^{1} \mathrm{O}_{2}$.

\subsection{Comparative Singlet Oxygen Generation Studies}

To each well of a 6-well plate was added $2 \mathrm{~mL}$ containing $50 \mu \mathrm{M}$ of 1,3diphenylisobenzofuran (DPBF) and $5 \mu \mathrm{M}$ of photosensitizers in DMSO. The plate was irradiated using a $71 \mathrm{~W}$ filtered light source of $>500 \mathrm{~nm}$ with a Schott glass $500 \mathrm{~nm}$ longpass yellow filter for 1 hour. At $15 \mathrm{~min}$ intervals, $200 \mu \mathrm{L}$ aliquots were removed from each of the six wells and the absorbance was measured at $410 \mathrm{~nm}$. The rate of singlet oxygen generation was determined by the decrease in absorbance of DPBF over time. A control solution of DPBF/methylene blue (reference standard) was irradiated under the above conditions. Absorption spectra were chronicled using a Varian Cary 50 Bio UV/VIS Spectrophotometer.

\subsection{Octanol-HEPES buffer coefficients}

The partition coefficients $(\log P)$ were measured at room temperature by adding $0.5 \mathrm{~mL}$ of a BODIPY stock solution in DMSO $(50 \mu \mathrm{M})$ to a $15 \mathrm{~mL}$ volumetric tube containing $4.0 \mathrm{~mL}$ of HEPES buffer (1 M, pH 7.4), followed by addition of $4.0 \mathrm{~mL}$ of 1-octanol. After vortexing for $5 \mathrm{~min}$, the phases were allowed to separate completely. An aliquot of $0.5 \mathrm{~mL}$ from each layer was diluted with $0.5 \mathrm{~mL}$ of methanol and the absorbance was read on an Agilent Technologies $8354 \mathrm{UV}$-Vis spectrophotometer with $10 \mathrm{~mm}$ path length quartz cuvette.

\section{Results and discussion}

\subsection{Syntheses and structural characterization}

We have recently reported the synthesis of BODIPY 1 via condensation of 2,4dimethylpyrrole with 3,5-dimethoxybenzaldehyde, followed by oxidation, boron complexation and iodination using iodic acid, in 33\% overall yield (4 steps) [26]. In order to increase the solubility and the absorption and emission maxima of BODIPY $1\left(\lambda_{\max }=535\right.$ and $549 \mathrm{~nm}$, respectively, in dichloromethane), one or two styryl groups were introduced via Knoevenagel condensation of the 3,5-dimethyl groups with polar aromatic aldehydes, as shown in Scheme 1.

The Knoevenagel reaction in the presence of excess aromatic aldehyde afforded the monoand di-styryl-BODIPYs 2a-e and 3a-e, respectively, in 15-40\% yields [23-25,38]. The 
reactions were performed in refluxing toluene, and molecular sieves were used to remove the water formed during the reaction. Since prolonged reflux led to significant decomposition of both starting materials and products [23-25,38], alternative reaction conditions were investigated to optimize product yields, including different reaction times, concentrations, equivalents of aryl aldehyde, temperatures, and microwave (400 W) radiation. The highest yields were obtained when the electron-rich indole-3-carbaldehyde and tri(ethyleneglycol)benzaldehyde 7 were used along with $400 \mathrm{~W}$ microwave irradiation at $90{ }^{\circ} \mathrm{C}$ for $1 \mathrm{~h}$. The microwave-assisted synthesis and functionalizations of BODIPYs have been previously investigated [40-42] and applied to Knoevenagle condensations [42]. This technique has the advantages of allowing shorter reaction times, producing high yields and low decomposition of products.

The aryl groups used to extend the $\pi$-conjugation of $\mathbf{1}$ were chosen to increase the styrylBODIPY solubility and cellular permeability, via insertion of a triethylene glycol or a heteroatom aromatic group, as we have recently explored [38]. The electron-withdrawing groups in 2d,e and 3d,e were introduced with the aim to increase the styryl-BODIPY's stability. The synthesis of tri(ethyleneglycol)benzaldehyde 7 was carried out in 3 steps from 4-hydroxybenzaldehyde, as previously reported (see Supporting Information). Protection of the aldehyde group to give $\mathbf{4}$, followed by reaction with tosyl tri(ethylene)glycol monomethyl ether $\mathbf{5}$, in the presence of $\mathrm{K}_{2} \mathrm{CO}_{3}$ in refluxing acetonitrile gave compound $\mathbf{6}$, which was deprotected using mercury perchlorate in THF affording tri(ethyleneglycol)benzaldehyde 7 [43] in $48 \%$ overall yield. The indole group was chosen to increase the wavelenghts of absorption and emission of the styryl-BODIPYs, and to enhance their biological efficacy due to its resemblance to the naturally occurring amino acid tryptophan, a key component in the structure of many enzymes and proteins, and a precursor of serotonin, melatonin, and niacin [44]. However, it was noted over the course of experimentation that BODIPYs 2a and 3a quickly decomposed $(<24 \mathrm{~h})$ when left in solution or in crystalline form under ambient light (see Supporting Information, Figures S2 and S3). For this reason, 5-nitroindole-3-carboxaldehyde, prepared according to the literature [45], was also used in the Knoevenagle condensation with $\mathbf{1}$ with the aim to enhance the stability of BODIPYs $\mathbf{2 d}$ and $\mathbf{3 d}$ relative to $\mathbf{2} \mathbf{a}$ and $\mathbf{3 a}$. The addition of the nitro group did enhance the stability of the BODIPYs, although significant decomposition was still observed with time for the indolylstyryl- and the pyrrolylstyryl-BODIPYs $\mathbf{2 a} / \mathbf{3 a}, \mathbf{2 d} / \mathbf{3 d}$ and $\mathbf{2 e / 3 e}$. The most stable BODIPYs of this series were $\mathbf{2 b / 3 b}$ and $\mathbf{2} \mathbf{c} / \mathbf{3 c}$. $1 \mathrm{H}-\mathrm{NMR}$ investigations of $\mathbf{2 d}$ and $\mathbf{3 d}$ in DMSO- $\mathrm{d}_{6}$ upon exposure to ambient light for up to 12 days were also conducted (see Supporting Information, Figure S4). Both compounds were stable up to 1 day, however decomposition was observed after that, particularly for the disubstituted BODIPY 3d. The integration of the NMR signals corresponding to the nitroindolylstyryl group of BODIPY 3d observed at $9.1(\mathrm{NH}), 8.8,8.4,8.2,7.8,7.7$, and 7.5 significantly decreased by day 12 , while signals corresponding to the nitroindolyl group could be identified as time progressed.

The structures of all BODIPYs synthesized were confirmed by ${ }^{1} \mathrm{H}$ - and ${ }^{13} \mathrm{C}-\mathrm{NMR}$, HRMS, and UV/VIS and fluorescence spectroscopies. Single crystals of $\mathbf{1}^{\mathbf{2}}$ and $\mathbf{3 b}$ suitable for X-ray analysis (see Figure 1) were grown from slow evaporation of acetone. The X-ray crystal 
structures of $\mathbf{1}$ and $\mathbf{3 b}$ revealed the expected planarity of the BODIPY core that extended through the 2,6-diiodo groups. The $\mathrm{C}_{9} \mathrm{BN}_{2}$ ring system exhibited mean deviation of $0.013 \AA$ for $\mathbf{1}$ and 0.011-0.035 $\AA$ for the four independent molecules of $\mathbf{3 b}$. In both cases the iodine atoms lie less than $0.11 \AA$ from these mean planes, and the methyl $\mathrm{C}$ atoms less than $0.06 \AA$. The meso-phenyl groups are roughly orthogonal to the core to reduce steric strain caused by the 1,7-dimethyls, forming dihedral angles of 79.97(2) ${ }^{\circ}$ for $\mathbf{1}$ and $88.9(2)-90.0(2)^{\circ}$ for the four independent molecules of $\mathbf{3 b}$. The boron atom possesses tetrahedral geometry with the $\mathrm{BF}_{2}$ groups also lying perpendicular to the BODIPY core, forming dihedral angles of $89.23(4)^{\circ}$ for $\mathbf{1}$ and $87.7(9)-89.3(10)^{\circ}$ for $\mathbf{3 b}$. Short intermolecular B-F... $\pi$ interactions are observed between one pair of independent molecules in the crystal of $\mathbf{3 b}$. The distances between the $\mathrm{F}$ atoms of one molecule and the centroids of the central ring of the $\mathrm{C}_{9} \mathrm{BN}_{2}$ ring system of another molecule are 2.750 and $2.767 \AA$. The polyether chains of $\mathbf{3 b}$ are very flexible, and the eight independent chains exhibit a wide variation of conformations in the solid. In the 1H-NMR spectra in $\mathrm{CDCl}_{3}$, the ortho-phenyl hydrogens for all BODIPYs (see Supporting Information) appear as doublets at $\sim 6.5 \mathrm{ppm}$, while the para-hydrogens are triplets slightly shifted downfield at $\sim 6.6 \mathrm{ppm}$. The styryl groups double bonds have a trans (E) configuration in all BODIPYs, as indicated by the coupling constants of the alkene protons, between 16.2-17.1 Hz, and as also seen in Figure 1. Significant differences were seen in the chemical shifts of the 1,3,5,7-methyl groups. In the case of BODIPY 1 the methyls appear as two sets of equivalent protons, at $2.5 \mathrm{ppm}$ for the 3,5-dimethyls and 1.5 ppm for the 1,7-dimethyls due to shielding by the meso-aryl group. Addition of one styryl arm creates asymmetry in the BODIPYs causing the methyl groups to appear as singlets at $2.7 \mathrm{ppm}, 1.6 \mathrm{ppm}$ and $1.5 \mathrm{ppm}$. The incorporation of the second styryl group restores symmetry and causes reappearance of a single signal for the 1,7-dimethyls at $1.6 \mathrm{ppm}$. Only slight changes in the chemical shifts of the styryl groups were observed in the ${ }^{1} \mathrm{H}$ - and ${ }^{13} \mathrm{C}$ NMR spectra of the mono- vs. di-styryl-BODIPYs. All spectra were recorded in deuterated chloroform, with exception of $\mathbf{3 d}$ and $\mathbf{3 e}$, which was obtained in DMSO- $\mathrm{d}_{6}$ and acetone- $\mathrm{d}_{6}$, respectively, due to their decreased solubility in chloroform and dichloromethane.

\subsection{Spectroscopic properties}

The spectroscopic characteristics of the BODIPYs were explored in dichloromethane, THF, and DMSO and the results obtained are shown in Figure 2, Table 1 and the Supporting Information, Figure S1. Incorporation of one styryl group onto the BODIPY core, as in 2ae, induced pronounced red-shifts in the absorption (59 - $98 \mathrm{~nm}$ ) and emission $(59-125 \mathrm{~nm})$ spectra, compared with BODIPY 1 in DMSO. Addition of a second styryl group induced even greater red-shifts of $126-189 \mathrm{~nm}$ and 129 - $220 \mathrm{~nm}$ for the absorption and emission, respectively, due to further extension of the $\pi$-conjugation. In addition, the absorption and emission bands become broader and more intense with increasing number of styryl substituents. All Q-band absorptions, due to the $\mathrm{S}_{0}-\mathrm{S}_{1}\left(\pi-\pi^{*}\right)$ electronic transition, show a shoulder at lower wavelength that is attributed to the vibrational transitions [42], and most pronounced for the styryl-BODIPYs, and in particular for BODIPY 3a in THF and dichloromethane solutions (Supporting Information, Figure S1). The broader and weaker

\footnotetext{
${ }^{2}$ The authors acknowledge Dr. Gregory McCandless preliminary work on the crystal structure of BODIPY 1.
} 
absorption bands seen in the absorption spectra of the styryl-BODIPYs centered at $460 \mathrm{~nm}$ are likely due to the $\mathrm{S}_{0}-\mathrm{S}_{2}$ transition [42]. In DMSO the Q-band absorptions of all BODIPYs strictly follow the Lambert-Beer's law (see Supporting Information, Figure S5), suggesting that there is no aggregation in this solvent. In addition, small to moderate red-shifts in $\lambda_{\max }$ (1-25 nm) were observed for the BODIPYs in DMSO, compared to THF and dichloromethane, indicating that excitation of the BODIPYs leads to more polarized excited states that are stabilized by the more polar solvent [42]. All BODIPYs displayed absorption maxima within the PDT biological window, between ca. 600 and $770 \mathrm{~nm}$ in DMSO, with large extinction coefficients $(\log \varepsilon=4.1-4.9)$. The Stokes shifts ranged from 219-1,053 $\mathrm{cm}^{-1}$ with the greater enhancement observed for the mono-styryl BODIPYs.

The presence of the 2,6-diiodo groups in the BODIPYs is expected to cause red-shifts in the absorption and emission of the BODIPY core due to lower HOMO-LUMO gap [23,26] as well as decrease in fluorescence quantum yields due to enhanced intersystem crossing from the excited singlet to the triplet state because of spin-orbit coupling by the heavy atom effect. Interestingly, the extension of $\pi$-conjugation via incorporation of the styryl groups, enhanced the fluorescence quantum yields of styryl-BODIPY 2a-e and 3a,b,e compared with $\mathbf{1}$. This effect was more pronounced in BODIPYs $\mathbf{2} \mathbf{b}$ and $\mathbf{3 b}$, bearing the triethylene glycol groups, maybe as a result of their enhanced aqueous solubility, despite the flexible chains $[24,25,46]$. Although the 2,6-iodines are expected to enhance production of singlet oxygen, the main cytotoxic species in PDT, we have recently shown that only a handful of 2,6-diiodo-BODIPYs containing different meso-substituents, are phototoxic to HEp2 cells [26]. The comparative singlet oxygen quantum yields of the BODIPYs relative to methylene blue $\left(\Phi_{\Delta}=0.52\right)$ were determined [26,32], and the results are shown in Table 2. In addition, the formation of singlet oxygen and hydroxyl radicals after irradiation of photosensitized cells was also determined [47] (vide infra).

\subsection{Cellular Properties}

The concentration-dependent dark and photo (light dose $\sim 1.5 \mathrm{~J} / \mathrm{cm}^{2}$ ) cytotoxicities of all BODIPYs were investigated in human carcinoma HEp2 cells using the Cell Titer Blue assay, and the results are shown in Figures 3 and 4 and summarized in Table 2 (see also Supporting Information, Figure S6). None of the BODIPYs were toxic in the dark $\left(\mathrm{IC}_{50}>\right.$ $400 \mu \mathrm{M})$, with exception of BODIPY 2a, which showed low cytoxicity $\left(\right.$ I C $\left._{50}=148 \mu \mathrm{M}\right)$. Upon exposure to low light dose $\left(\sim 1.5 \mathrm{~J} / \mathrm{cm}^{2}\right)$ all the mono-styryl-BODIPYs showed high phototoxicity with $\mathrm{IC}_{50}$ values between $2-15 \mu \mathrm{M}$, while the di-styryl-BODIPY were much less phototoxic with determined $\mathrm{IC}_{50}>100 \mu \mathrm{M}$. It has been previously shown that the presence of electron-donating alkoxyphenyl substituents at the 8-position and two iodides or bromides at the 2,6-positions [23-26], as in BODIPY 1, induces high phototoxicity with no detectable dark cytotoxicity. It is interesting that in this series of compounds, the monostyryl BODIPYs retain the phototoxic properties of BODIPY 1 but the di-styryl BODIPYs do not, although the comparative singlet oxygen quantum yields determined using DPBF as acceptor [26,32] (see Table 2), suggest that all BODIPYs can produce singlet oxygen. The formation of singlet molecular oxygen $\left({ }^{1} \mathrm{O}_{2}\right)$ and hydroxyl radical $\left({ }^{\circ} \mathrm{OH}\right)$ after irradiation of photosensitized cells was determined using murine hepatoma 1c1c7 cells and fluorescent probes APF and DADB, as previously described [47]. APF is a highly selective probe 
for ${ }^{\circ} \mathrm{OH}$ [48] while DADB is a cell-permeable probe for ${ }^{1} \mathrm{O}_{2}$ [49]. We have previously used these probes to assess ROS formation as a result of photodynamic processes [50]. The results shown in Figure 4 indicate that irradiation of 1c1c7 cells photosensitized by BODIPY 2a results in formation of ${ }^{\bullet} \mathrm{OH}$ but not ${ }^{1} \mathrm{O}_{2}$. A similar treatment with 3a produced no detectable decrease in the fluorescence signal. While these are only qualitative results, they provide information on the ability of these agents to produce ROS in a cellular environment, and might explain the observed phototoxicity of the mono-styryl-BODIPYs in comparison with the di-styryl-BODIPY derivatives. Similar studies on HEp2 cells have not yet been carried out, but in our experience, there is little variation in ROS production as a function of cell type.

The high phototoxicity observed for the mono-styryl-BODIPYs might be due to their unsymmetric structure, which favors their cellular uptake and/or their binding to specific intracellular proteins. On the other hand, the symmetric structure of the di-styryl-BODIPYs induces low or no phototoxicity. Nevertheless, Akkaya et al. [23] and $\mathrm{Ng}$ et al. [24] reported several symmetric 3,5-distyryl-BODIPYs containing 2,6-diiodo or 2,6-dibromo substituents that were phototoxic to K562 and HT20 cells, respectively, at much higher light doses. The most phototoxic compound in these studies contained five triethylene glycol chains $\left(\mathrm{IC}_{50}=\right.$ $7 \mathrm{nM}$ at $48 \mathrm{~J} / \mathrm{cm}^{2}$ ) and its phototoxicity was attributed to its high cellular uptake and preferential localization in the cell ER. Unsymmetrical distyryl-2,6-diiodo-BODIPYs bearing three ethylene glycol groups and amine functionalities were also found to be phototoxic to HT29 cells (as low as $\mathrm{IC}_{50}=15 \mathrm{nM}$ at $48 \mathrm{~J} / \mathrm{cm}^{2}$ ), due in part to their partial localization in cell mitochondria [25]. We recently reported [26] that the phototoxicity of 2,6-diiodo-BODIPYs depends on the nature of the 8-substituent, and BODIPY 1 was among the most phototoxic $\left(\mathrm{IC}_{50}=4 \mu \mathrm{M}\right.$ at $1.5 \mathrm{~J} / \mathrm{cm}^{2}$ ) of a series of eleven 2,6-diiodo-BODIPYs investigated with varying 8-substituents. Extension of the $\pi$-conjugation of BODIPY 1 via introduction of one styryl group, as in $\mathbf{2 a - e}$, still afforded highly phototoxic derivatives, while the introduction of a second styryl group, as in 3a-e, decreased phototoxicity and the ability for producing ROS in cells. We have also reported that mono- and distyryl-BODIPYs without the 2,6-diiodo groups show no phototoxicity to HEp2 cells [38]; the introduction of iodides at the 2,6-positions induces phototoxicity in the mono-styryl-BODIPYs but not on the di-styryl-BODIPYs. Our results suggest that while the phototoxic mono-styrylBODIPYs $\mathbf{2 a - e}$ are promising photosensitizers for PDT, particularly $\mathbf{2 a}(\varepsilon \sim 29,000$ $\mathrm{M}^{-1} . \mathrm{cm}^{-1}$ at $\lambda_{\max } 636 \mathrm{~nm}, \Phi_{\Delta}=0.72$ ), the di-styryl-BODIPYs of low dark and photo cytotoxicities, particularly $\mathbf{3 b}\left(\lambda_{\max }\right.$ emission at $\left.697 \mathrm{~nm}, \Phi_{\mathrm{f}}=0.44\right)$, are promising fluorophores for near-IR bioimaging.

To further investigate the cause of phototoxicity in this series of BODIPYs, the cellular uptake was evaluated over a period of $24 \mathrm{~h}$, and the results from these studies are shown in Figures 5-11 (and Supporting Information, Figures S7-S11). All BODIPYs were quickly and efficiently internalized by cells, although the extent of their uptake did not correlate with their hydrophobic character, as determined by their partition coefficients $(\log P)$ [51] in octanol-HEPES buffer $\mathrm{pH}=7.4$, shown in Table 2. In general, higher hydrophobic character was observed with increasing number of styryl groups. BODIPYs $\mathbf{2 b , \mathbf { e }}$ and 3a,d were taken up very quickly in the first $2 \mathrm{~h}$, but after $24 \mathrm{~h}$, BODIPYs $\mathbf{2 a - c}$ and $\mathbf{3 d}, \mathbf{e}$ were found the most 
within cells, while $\mathbf{2 e}$ accumulated the least. In all cases except for BODIPYs $\mathbf{2 e}$ and $\mathbf{3 a}$, the amount of BODIPY taken up by the cells increased significantly from 8 to $24 \mathrm{~h}$. Following 6 $\mathrm{h}$ uptake into cells, the subcellular localization of the BODIPYs was investigated by fluorescence microscopy. Organelle-specific fluorophores BODIPY Ceramide (Golgi), LysoSensor Green (lysosomes), MitoTracker Green (mitochondria), and ER Tracker Blue/ White (ER) were used in the overlay experiments. The purple or yellow/orange colors indicate co-localization of BODIPY and organelle tracker. All BODIPYs localized in multiple organelles, including the lysosomes, Golgi, ER and the cell mitochondria. While the major sites of localization for the mono-styryl-BODIPYs were found to be the ER, lysosomes and mitochondria, the di-styryl-BODIPYs accumulated preferentially in the Golgi, and to a lower extent in the ER and mitochondria. This result, along with their ability for producing ROS in cells (see above), is responsible for the observed higher phototoxicity of the mono-styryl-diiodo-BODIPYs relative to their di-styryl analogs. Both the ER and mitochondria are important PDT targets, and accumulation of photosensitizer in these organelles can lead to rapid cell death due to photodamage to anti-apoptotic Bcl-2 proteins located in the ER and mitochondrial membranes, and/or by direct mitochondrial photodamage [52]. It is possible that the mono-styryl-diiodo-BODIPYs bind preferentially to anti-apoptotic Bcl-2 proteins compared with their di-styryl analogs, causing cell apoptosis and/or autophagy [53], leading to rapid cell death. Previous studies have also shown that phototoxic BODIPYs tend to localize preferentially in the ER or mitochondria [24-29].

\section{Conclusions}

A series of mono- and di-styryl-diiodo-BODIPYs with absorptions and emissions in the ca. 600-770 nm region were synthesized via Knoevenagel condensations on a 2,6-diiodo-3,5dimethyl-BODIPY (1), in yields up to $40 \%$ upon microwave irradiation $\left(90^{\circ} \mathrm{C}\right.$ for $1 \mathrm{~h}$ at 400 W). Indolyl-, tri(ethyleneglycol)phenyl-, thienyl-, and pyrrolyl-containing styryl groups were introduced with the aim to red-shift the absorption and emission profiles of phototoxic BODIPY 1, as well as to increase its stability, solubility, and cellular permeability. The Xray structure of a di-styryl-BODIPY $\mathbf{3 b}$ was obtained, showing the planarity and symmetry of the BODIPY core, and the $E$ configurations of the styryl groups. The extension of $\pi$ conjugation in BODIPY 1 produced 59-125 nm red-shifts in the absorption and emission bands of the mono-styryl- and $126-220 \mathrm{~nm}$ in the di-styryl-BODIPYs in DMSO. The indolylstyryl- and pyrrolylstyryl-BODIPYs decomposed upon light exposure, even when substituted with electron-withdrawing groups $\left(-\mathrm{NO}_{2},-\mathrm{CO}_{2} \mathrm{Et}\right)$; on the other hand the tri(ethylene glycol)phenyl- and thienyl-styryl-BODIPYs were stable under similar light conditions. The mono-styryl-2,6-diiodo-BODIPYs were found to produce ROS in murine hepatoma cells and to display high phototoxicity $\left(\mathrm{IC}_{50}<15 \mu \mathrm{M}\right.$ at $\left.1.5 \mathrm{~J} / \mathrm{cm}^{2}\right)$ toward $\mathrm{HEp} 2$ cells. The lower symmetry of the mono-styryl-BODIPYs and their preferential localization within cell ER and mitochondria may favor their binding to intracellular proteins, such as the anti-apoptotic Bcl-2 found in these organelles. On the other hand, the distyryl-2,6diiodo-BODIPYs did not produce ROS in cells and had low or no phototoxicity $\left(\mathrm{IC}_{50}>100\right.$ $\mu \mathrm{M}$ at $1.5 \mathrm{~J} / \mathrm{cm}^{2}$ ). Among this series of compounds, BODIPYs 2a-e show the most promise for application as photosensitizers in PDT, while 3a-e are promising near-IR fluorescent imaging agents. Among these, BODIPY 2a was found to strongly absorb at $\lambda_{\max } 636 \mathrm{~nm}$ in 
DMSO, with high extinction coefficient $\left(\sim 29,000 \mathrm{M}^{-1} . \mathrm{cm}^{-1}\right)$, about 10-fold higher than Photofrin ${ }^{\circledR}$, it was the most phototoxic among the BODIPYs investigated $\left(\mathrm{IC}_{50}=2 \mu \mathrm{M}\right.$ at 1 $\mathrm{J} / \mathrm{cm}^{2}$ with a dark/phototoxicity ratio of 74), probably as a result of efficient ROS generation within cells, and is therefore particularly promising as a PDT photosensitizer. On the other hand, BODIPY 3b shows near-IR emission at $\lambda_{\max } 695 \mathrm{~nm}$ in DMSO, with fluorescence quantum yield of $\Phi_{\mathrm{f}}=0.2$ despite the 2,6-diiodo groups that favor intersystem crossing, and therefore is a promising near-IR imaging agent.

\section{Supplementary Material}

Refer to Web version on PubMed Central for supplementary material.

\section{Acknowledgements}

This work was partially supported by the National Science Foundation, grant number CHE-1362641, and by the National Institutes of Health, grant number R01-CA179902.

\section{References}

1. Karolin J, Johansson LBA, Strandberg L, Ny T. J. Am. Chem. Soc. 1994; 116:7801-7806.

2. Ehrenschwender T, Wagenknechet HA. J. Org. Chem. 2011; 76:2301-2304. [PubMed: 21381720]

3. Giessler K, Griesser H, Gohringer D, Sabirov T, Richert C. Eur. J. Org. Chem. 2010:3611-3620.

4. Kalai T, Hideg K. Tetrahedron. 2006; 62:10352-10360.

5. Jones LJ, Upson RH, Haugland RP, PanchukVoloshina N, Zhou MJ, Haugland RP. Anal. Biochem. 1997; 251:144-152. [PubMed: 9299009]

6. Bandhuvula P, Li ZG, Bittman R, Saba JD. Biochem. Biophys. Res. Commun. 2009; 380:366-370. [PubMed: 19250638]

7. Ziessel R, Ulrich G, Harriman A, Alamiry MAH, Stewart B, Retailleau P. Chem. Eur. J. 2009; 15:1359-1369. [PubMed: 19115286]

8. Baruah M, Qin WW, Vallee RAL, Beljonne D, Rohand T, Dehaen W, Boens N. Org. Lett. 2005; 7:4377-4380. [PubMed: 16178537]

9. Wu YK, Peng XJ, Guo BC, Fan JL, Zhang ZC, Wang JY, Cui AJ, Gao YL. Org. Biomol. Chem. 2005; 3:1387-1392. [PubMed: 15827633]

10. Jiao LJ, Li JL, Zhang SZ, Wei C, Hao EH, Vicente MGH. New J. Chem. 2009; 33:1888-1893.

11. Loudet A, Ueno Y, Wu LX, Jose J, Barhoumi R, Burghardt R, Burgess K. Bioorg. Med. Chem. Lett. 2011; 21:1849-1851. [PubMed: 21316231]

12. Dolmans D, Fukumura D, Jain RK. Nat. Rev. Cancer. 2003; 3:380-387. [PubMed: 12724736]

13. Dougherty TJ, Gomer CJ, Henderson BW, Jori G, Kessel D, Korbelik M, Moan J, Peng Q. J. Natl. Cancer Inst. 1998; 90:889-905. [PubMed: 9637138]

14. Brown SB, Brown EA, Walker I. Lancet Oncol. 2004; 5:497-508. [PubMed: 15288239]

15. Huang Z. Technol. Cancer Res. Treat. 2005; 4:283-293. [PubMed: 15896084]

16. Triesscheijn M, Baas P, Schellens JHM, Stewart FA. Oncologist. 2006; 11:1034-1044. [PubMed: 17030646]

17. Luo SL, Zhang EL, Su YP, Cheng TM, Shi CM. Biomaterials. 2011; 32:7127-7138. [PubMed: 21724249]

18. Pandey, RK.; Zheng, G. The Porphyrin. In: Kadish, KM.; Smith, KM.; Guilard, R., editors. Handbook. Vol. 6. Academic Press; 2000. p. 157-230.

19. Awuah SG, You Y. RSC Adv. 2012; 2:11169-11183.

20. Kamkaew A, Lim SH, Lee HB, Kiew LV, Chung LY, Burgess K. Chem. Soc. Rev. 2013; 42:7788. [PubMed: 23014776]

21. Ulrich G, Ziessel R, Harriman A. Angew. Chem. Int. Ed. 2008; 47:1184-1201. 
22. Loudet A, Burgess K. Chem. Rev. 2007; 107:4891-4932. [PubMed: 17924696]

23. Atilgan S, Ekmekci Z, Dogan AL, Guc D, Akkaya EU. Chem. Commun. 2006:4398-4400.

24. He H, Lo P-C, Yeung S-L, Fong W-P, Ng DKP. J. Med. Chem. 2011; 54:3097-3102. [PubMed: 21417218]

25. He H, Lo P-C, Yeung S-L, Fong W-P, Ng DKP. Chem. Commun. 2011; 47:4748-4750.

26. Gibbs JH, Robins LT, Zhou Z, Bobadova-Parvanova P, Cottam M, McCandless GT, Fronczek FR, Vicente MGH. Bioorg. Med. Chem. 2013; 21:5770-5781. [PubMed: 23928070]

27. Ke M-R, Yeung S-L, Ng DKP, Fong W-P, Lo P-C. J. Med. Chem. 2013; 56:8475-8483. [PubMed: 24088087]

28. Yang Y, Guo Q, Chen H, Zhou Z, Guo Z, Shen Z. Chem. Commun. 2013; 49:3940-3942.

29. Gallagher WM, Allen LT, O'Shea C, Kenna T, Hall M, Killoran J, OShea DF, J Cancer Br. 2005; 92:1702-1710.

30. Ortiz MJ, Agarrabeitia AR, Duran-Sampedro G, Prieto JB, Lopez TA, Massad WA, Montejano HA, Garcia NA, Arbeloa IL. Tetrahedron. 2012; 68:1153-1162.

31. Yogo T, Urano Y, Ishitsuka Y, Maniwa F, Nagano T. J. Am. Chem. Soc. 2005; 127:12162-12163. [PubMed: 16131160]

32. Lim SH, Thivierge C, Nowak-Sliwinska P, Han JY, van den Bergh H, Wagnieres G, Burgess K, Lee HB. J. Med. Chem. 2010; 53:2865-2874. [PubMed: 20199028]

33. Khalil, MME. Basic Sciences of Nuclear Medicine. Springer-Verlag: Berlin Heidelberg; 2011.

34. Li ZB, Lin TP, Liu SL, Huang CW, Hudnall TW, Gabbai FP, Conti PS. Chem. Commun. 2011; 47:9324-9326.

35. Liu SL, Lin TP, Li D, Leamer L, Shan H, Li ZB, Gabbai FP, Conti PS. Theranostics. 2013; 3:181189. [PubMed: 23471211]

36. Hendricks JA, Keliher EJ, Wan DP, Hilderbrand SA, Weissleder R, Mazitschek R. Angew. Chem. Int. Ed. 2012; 51:4603-4606.

37. Pandey SK, Sajjad M, Chen Y, Zheng X, Yao R, Missert JR, Batt C, Nabi HA, Oseroff AR, Pandey RK. J. Med. Chem. 2009; 52:445-455. [PubMed: 19090663]

38. Uppal T, Bhupathiraju N, Vicente MGH. Tetrahedron. 2013; 69:4687-4693.

39. Andrzejak M, Price M, Kessel DH. Autophagy. 2011; 7:979-984. [PubMed: 21555918]

40. Rohand T, Qin W, Boens N, Dehaen W. Eur. J. Org. Chem. 2006:4658-4663.

41. Kajiwara Y, Nagai A, Chujo Y. J. Mater. Chem. 2010; 20:2985-2992.

42. Baruah M, Qin W, Flors C, Hofkens J, Vallée RAL, Beljonne D, Van der Auweraer M, De

Borggrave WM, Boens N. J. Phys. Chem. A. 2006; 110:5998-6009. [PubMed: 16671668]

43. Triesscheijn M, Baas P, Schellens JHM, Stewart FA. Oncologist. 2006; 11:1034-1044. [PubMed: 17030646]

44. Sharma V, Kumar P, Pathak D. J. Heter. Chem. 2010; 47:491-502.

45. Nishimura T, Yamada K, Takebe T, Yokoshima S, Fukuyama T. Org. Lett. 2008; 10:2601-2604. [PubMed: 18484732]

46. Zhu S, Zhang J, Vegesna G, Luo F-T, Green SA, Liu H. Org. Lett. 2011; 13:438-441. [PubMed: 21175151]

47. Price M, Heilbrun L, Kessel DH. Photochem. Photobiol. 2013; 89:683-686. [PubMed: 23216021]

48. Setsukinai K, Urano Y, Kakinuma K, Majima HJ, Nagano T. J. Biol. Chem. 2003; 278:3170-3175. [PubMed: 12419811]

49. Oliveira MS, Severino D, Prado FM, Angeli JP, Motta FD, Baptista MS, Medeiros MH, Di Mascio P. Photochem Photobiol Sci. 2011; 10:1546-1555. [PubMed: 21735018]

50. Kessel D, Price M. Photochem. Photobiol. 2012; 88:717-720. [PubMed: 22296586]

51. Sangster J. J. Phys Chem. Ref. Data. 1989; 18:1111-1229.

52. Kessel D. J. Porphyrins Phthalocyanines. 2004; 8:1009-1014.

53. Kessel D, Oleinick NL. Methods in Enzymology. 2009; 453:1-16. [PubMed: 19216899]

J Photochem Photobiol B. Author manuscript; available in PMC 2016 April 01. 


\section{Highlights}

- A series of mono- and di-styryl-diiodo-BODIPYs were synthesized and investigated

- The mono-styryl-diiodo-BODIPYs were found to be phototoxic to HEp2 cells and are promising photosensitizers for PDT

- The di-styryl-diiodo-BODIPYs were not phototoxic to HEP2 cells and are promising near-IR fluorophores for bioimaging 

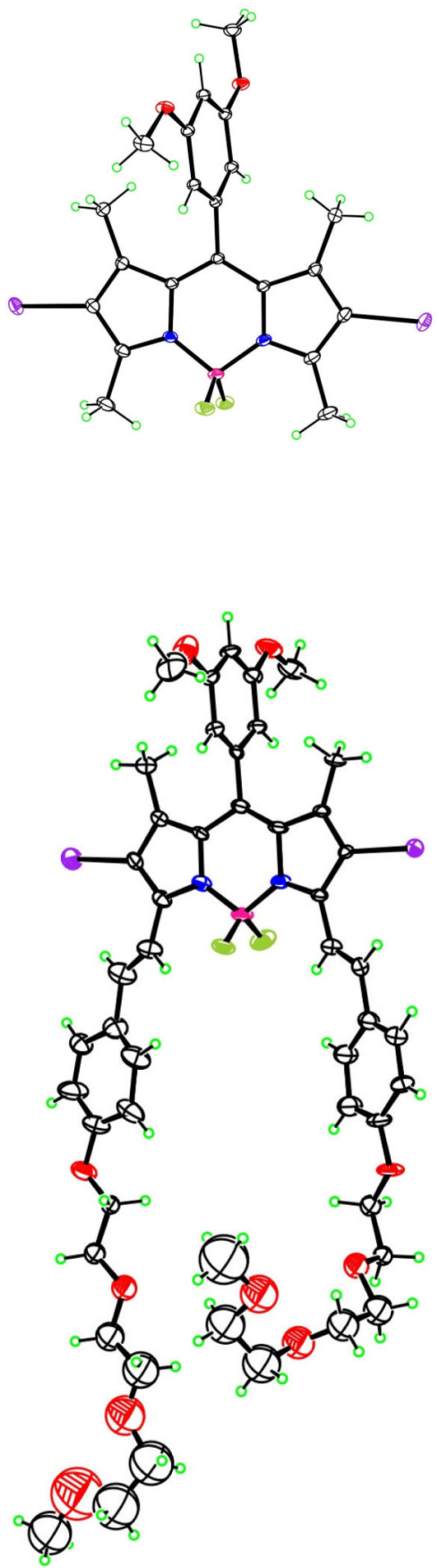

Figure 1.

Molecular structures of BODIPYs $\mathbf{1}$ and one of the four independent molecules of $\mathbf{3 b}$, from X-ray crystal structure determinations. Ellipsoids are drawn at the 50\% probability level. 


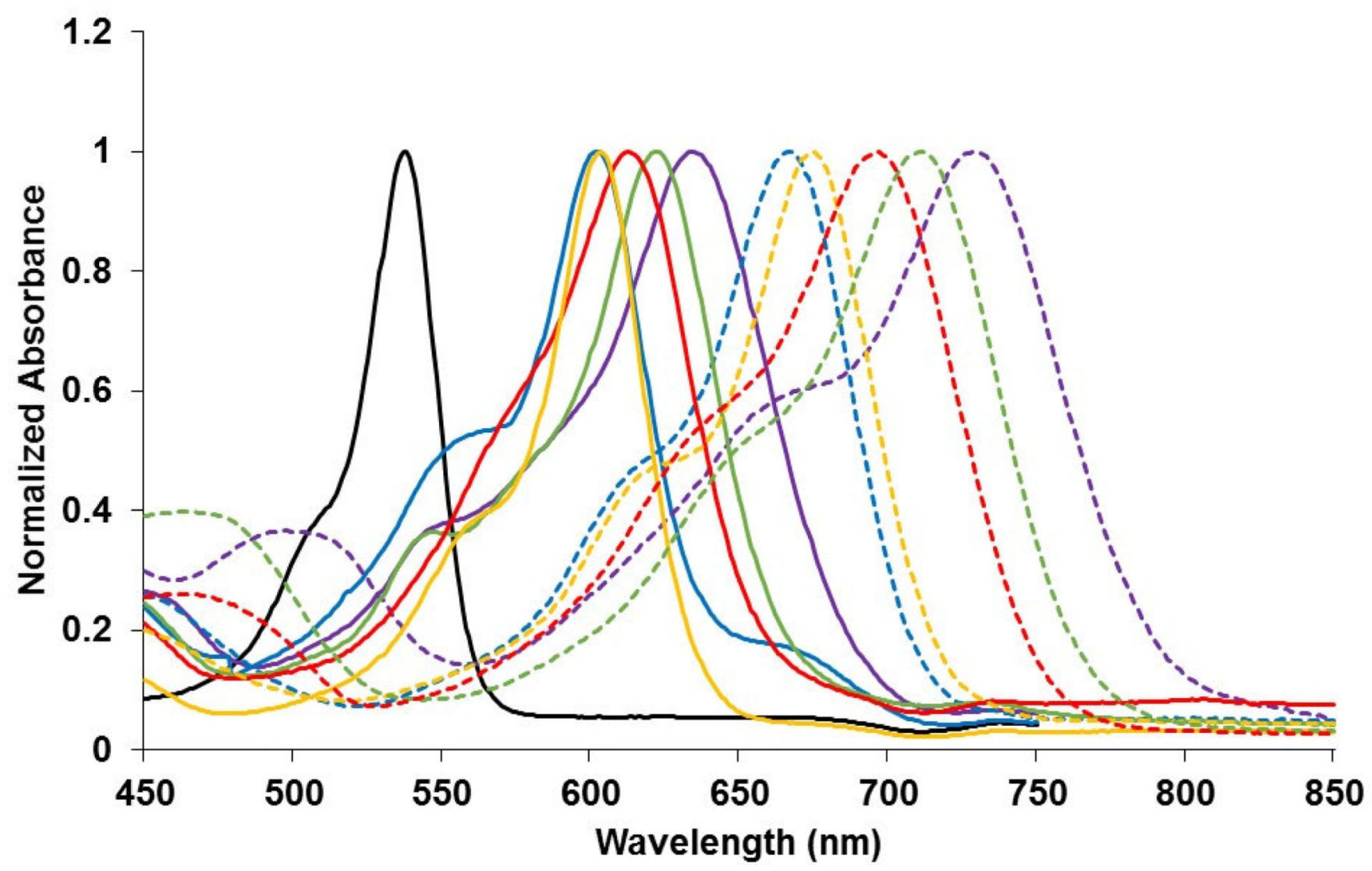

Figure 2.

Normalized absorption of BODIPYs 1 (hollow triangle, solid line), 2a ( full triangle, solid line), $\mathbf{2 b}$ (hollow circle, solid line), $2 \mathbf{c}$ (full circle, solid line), 2d (hollow square, solid line), $\mathbf{2 e}$ (full square, solid line), 3a (full triangle, dash line), 3b (hollow circle, dash line), 3c (full circle, dash line), 3d (hollow square, dash line), and $\mathbf{3 e}$ (full square, dash line) in DMSO at room temperature. 


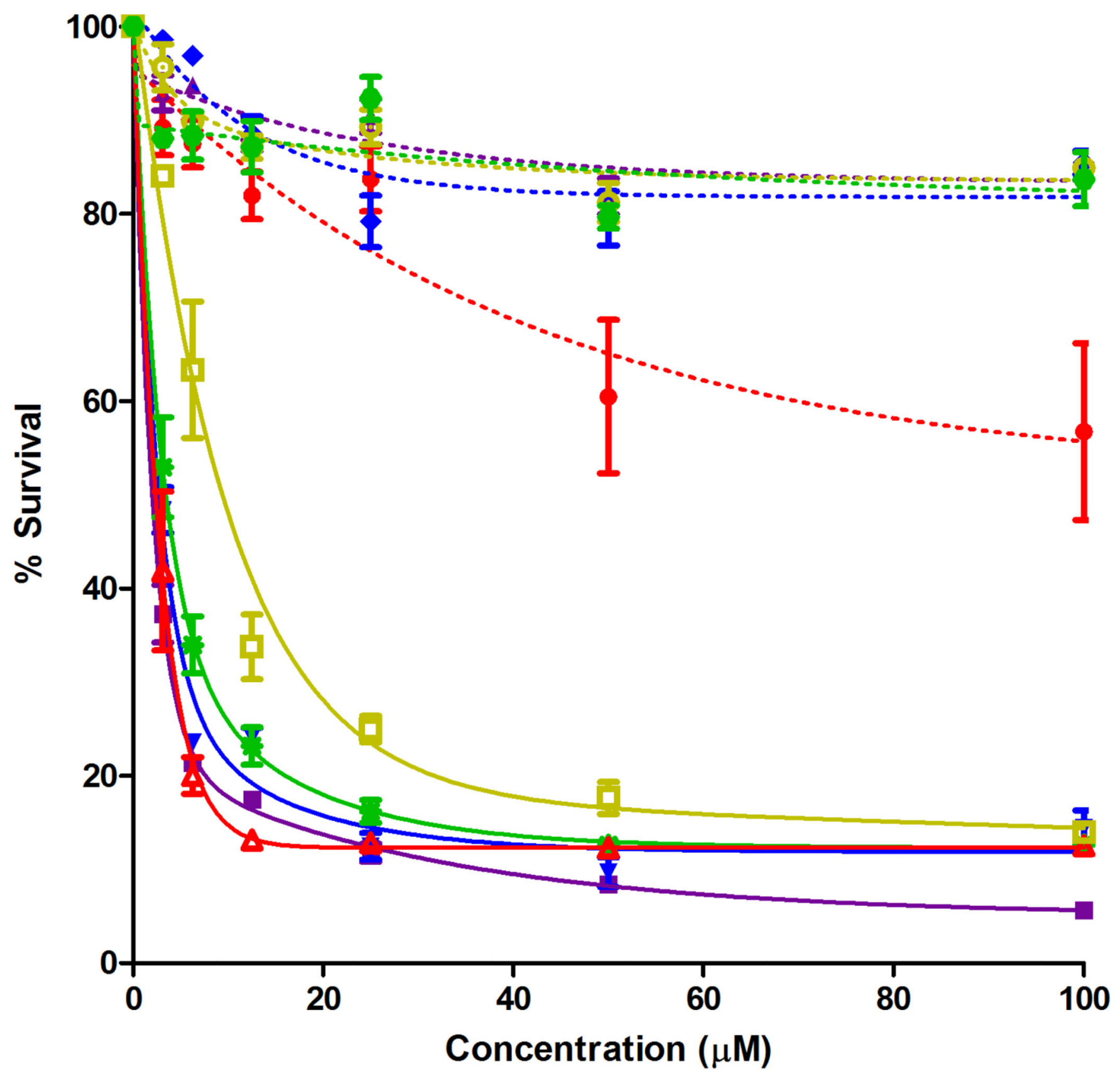

Figure 3.

Phototoxicity (1.5 J/cm ${ }^{2}$ ) of BODIPYs $2 \mathbf{a}$ (full square, solid line), $\mathbf{2 b}$ (full down triangle, solid line), 2c (hollow square, solid line), 2d (full star, solid line), 2e (hollow up triangle, solid line), 3a (full up triangle, dash line), 3b (full diamond, dash line), 3c (hollow circle, dash line), 3d (full hexagon, dash line), and 3e (full circle, dash line) at $10 \mu \mathrm{M}$ by HEp2 cells. 


\section{APF}

dark
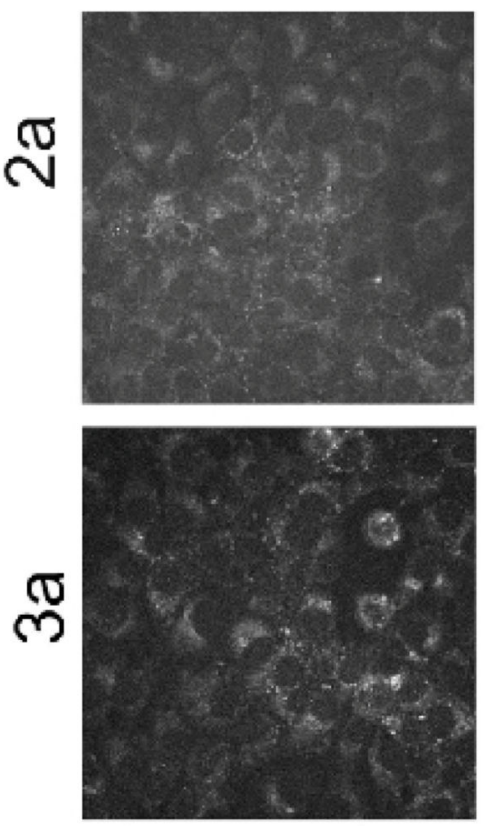

$1 \mathrm{~min}$
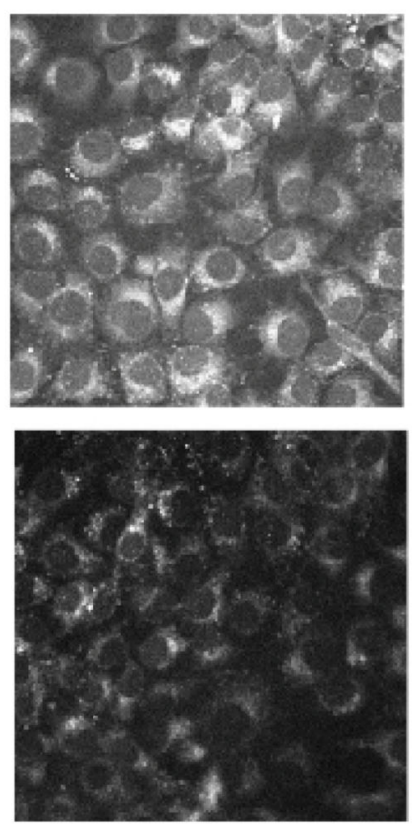

DADB

dark
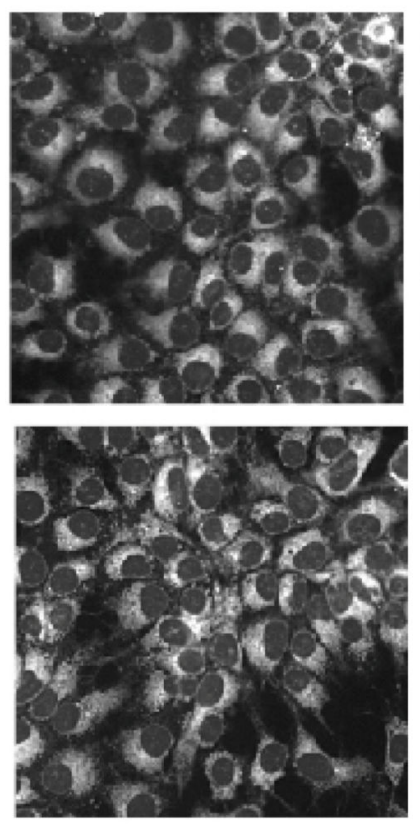

$1 \mathrm{~min}$
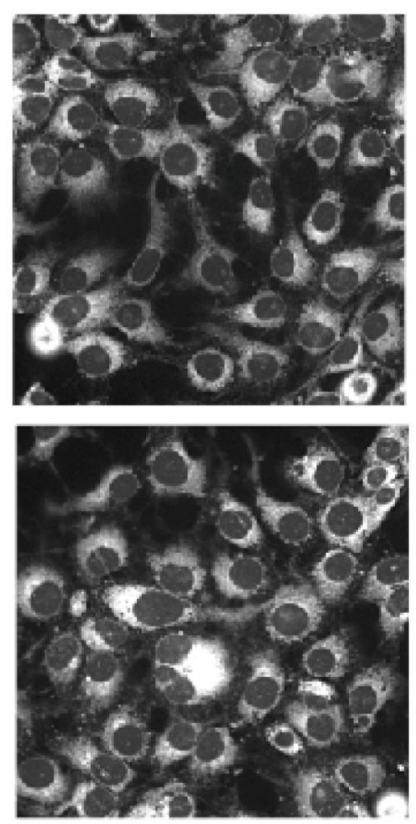

Figure 4.

AFP and DADB fluorescence in control (dark) vs. irradiated 1c1c7 cells: effects of BODIPYs 2a and 3a. These results reflect formation of ${ }^{\circ} \mathrm{OH}$ (APF) as indicated by increased fluorescence, and of ${ }^{1} \mathrm{O}_{2}$ as detected by DADB (decreased fluorescence). These results represent the results of a typical experiment. 


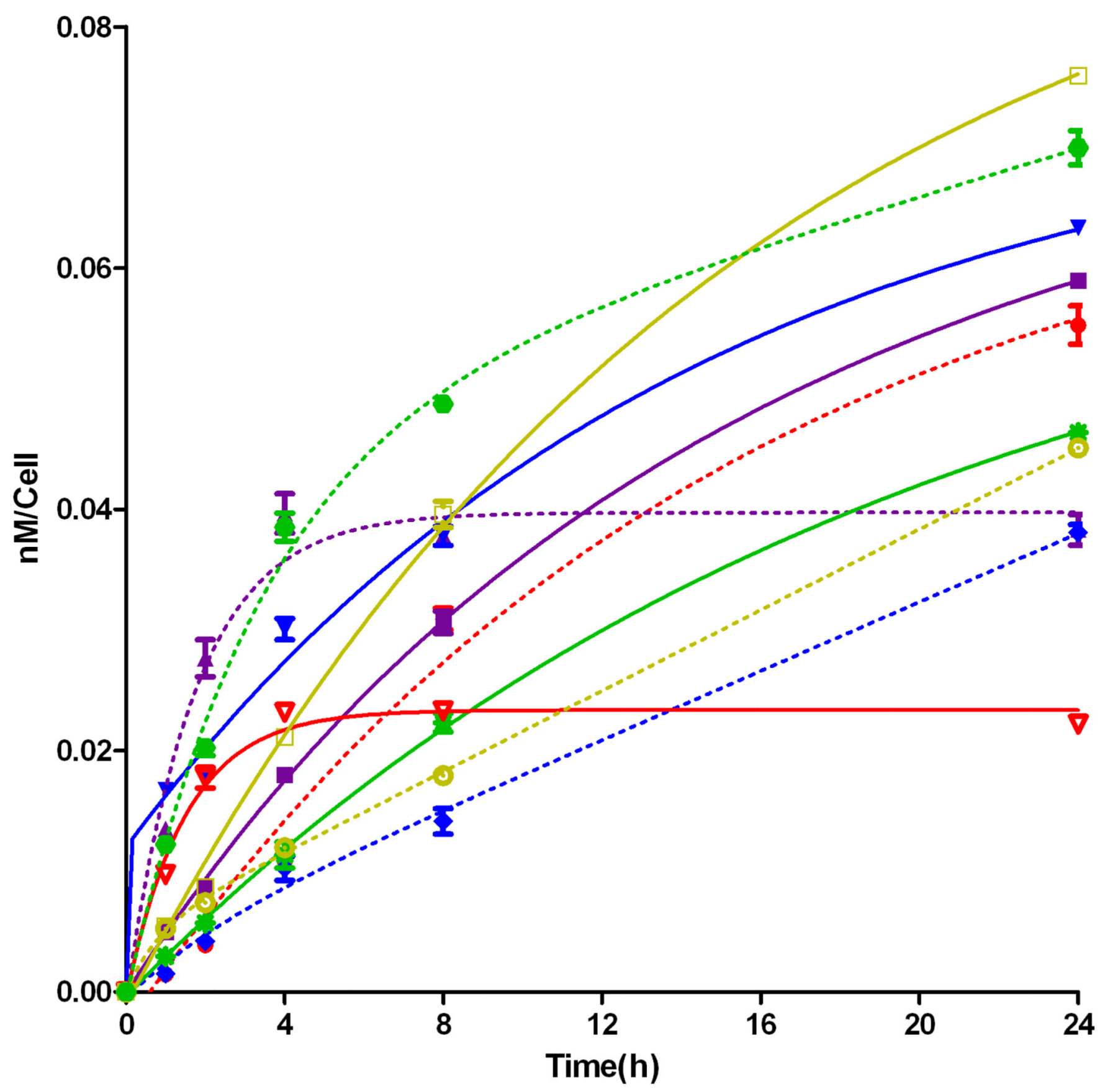

Figure 5.

Time-dependent cellular uptake of BODIPYs $\mathbf{2 a}$ (full square, solid line), $\mathbf{2 b}$ (full down triangle, solid line), 2c (hollow square, solid line), 2d (full star, solid line), $2 \mathbf{e}$ (hollow up triangle, solid line), 3a (full up triangle, dash line), $\mathbf{3 b}$ (full diamond, dash line), 3c (hollow circle, dash line), 3d (full hexagon, dash line), and $\mathbf{3 e}$ (full circle, dash line) at $10 \mu \mathrm{M}$ by HEp2 cells 


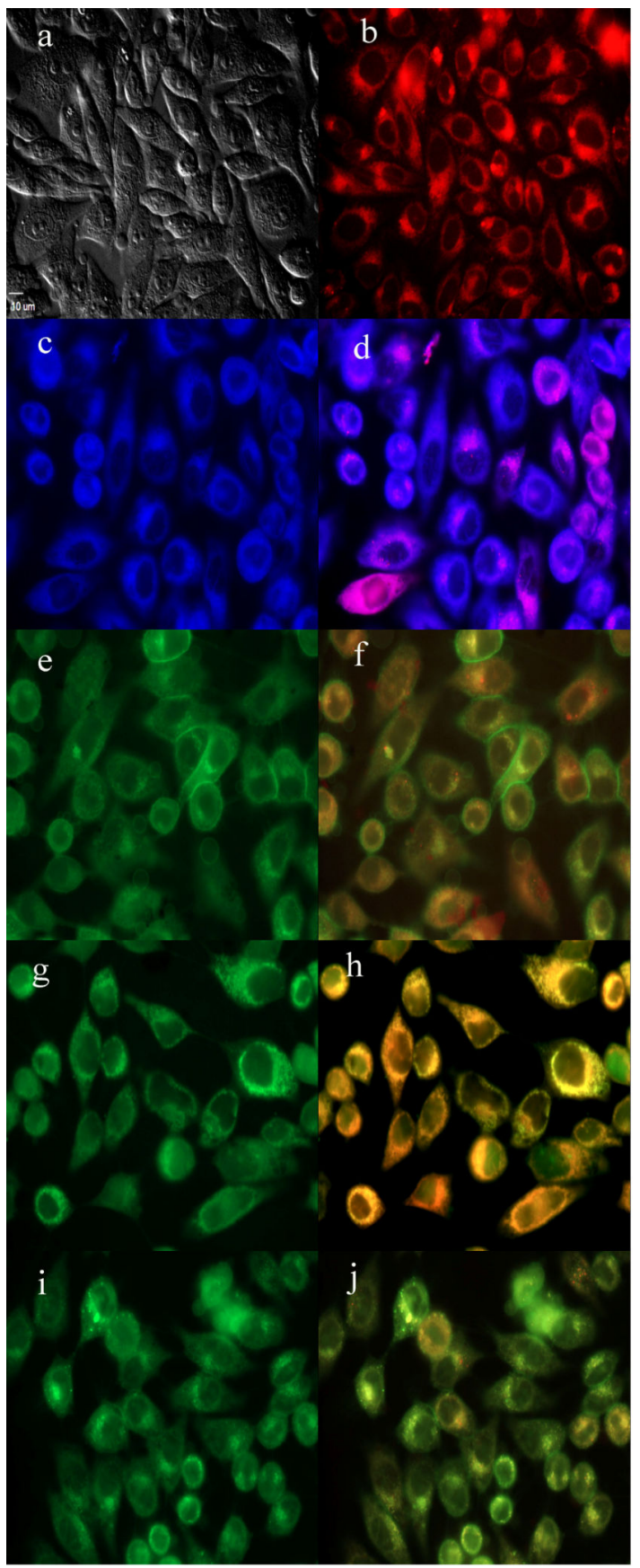

Figure 6.

Subcellular localization of BODIPY $2 \mathbf{a}$ in HEp2 cells at $10 \mu \mathrm{M}$ for $6 \mathrm{~h}$. a) Phase contrast, b) 2a fluorescence, c) ER tracker blue/white fluorescence, e) MitoTracker green fluorescence, g) BODIPY Ceramide, i) LysoSensor green fluorescence, and d), f), h), and j) overlays of organelle tracers with the BODIPY fluorescence. Scale bar: $10 \mu \mathrm{m}$. 


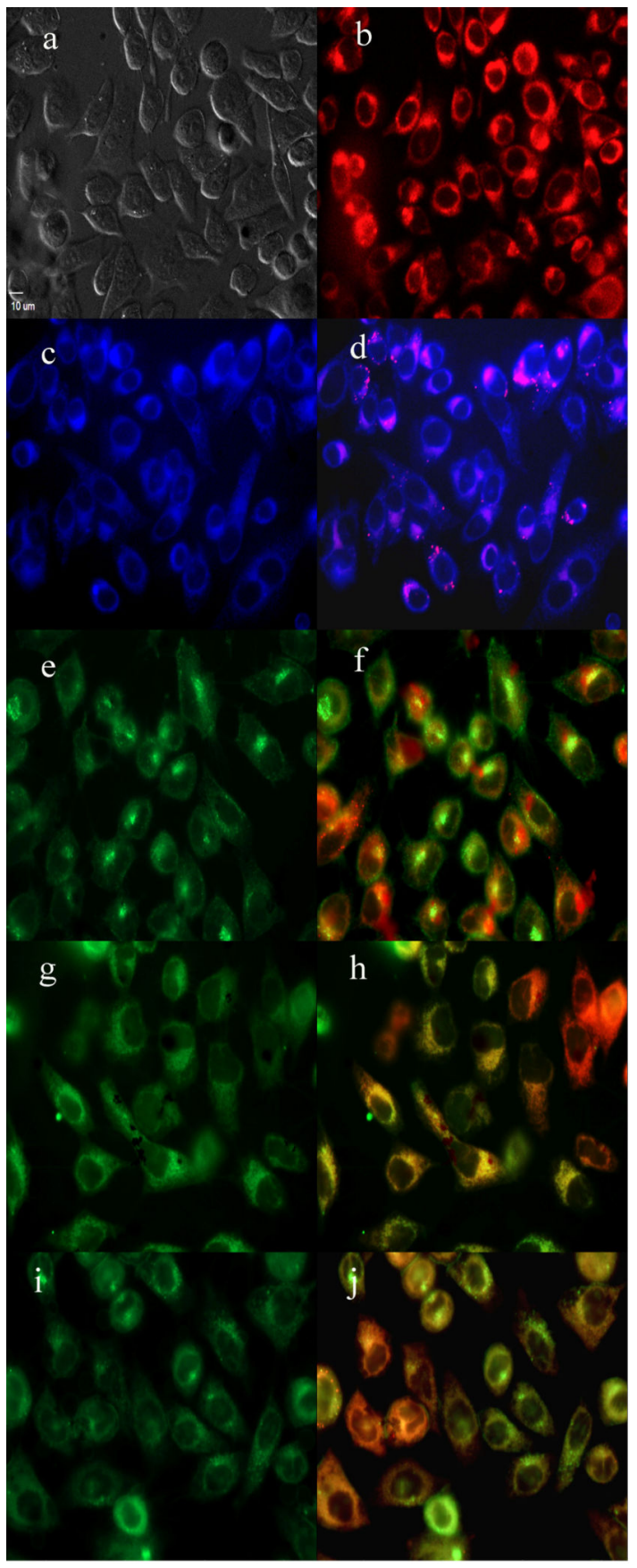

Figure 7.

Subcellular localization of BODIPY $\mathbf{2 b}$ in HEp2 cells at $10 \mu \mathrm{M}$ for $6 \mathrm{~h}$. a) Phase contrast, b) 2b fluorescence, c) ER tracker blue/white fluorescence, e) MitoTracker green fluorescence, g) BODIPY Ceramide, i) LysoSensor green fluorescence, and d), f), h), and j) overlays of organelle tracers with the BODIPY fluorescence. Scale bar: $10 \mu \mathrm{m}$. 

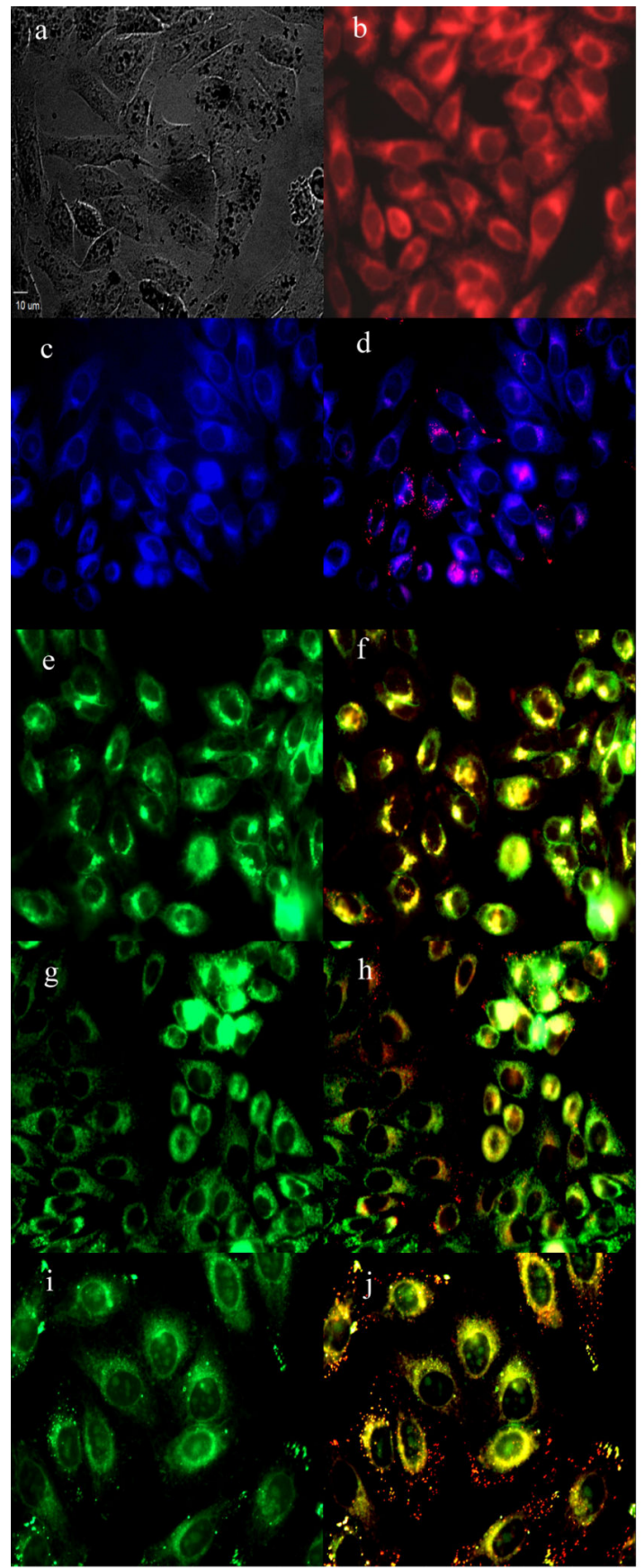

Figure 8.

Subcellular localization of BODIPY $2 \mathrm{c}$ in HEp2 cells at $10 \mu \mathrm{M}$ for $6 \mathrm{~h}$. a) Phase contrast, b) 2c fluorescence, c) ER tracker blue/white fluorescence, e) MitoTracker green fluorescence, g) BODIPY Ceramide, i) LysoSensor green fluorescence, and d), f), h), and j) overlays of organelle tracers with the BODIPY fluorescence. Scale bar: $10 \mu \mathrm{m}$. 


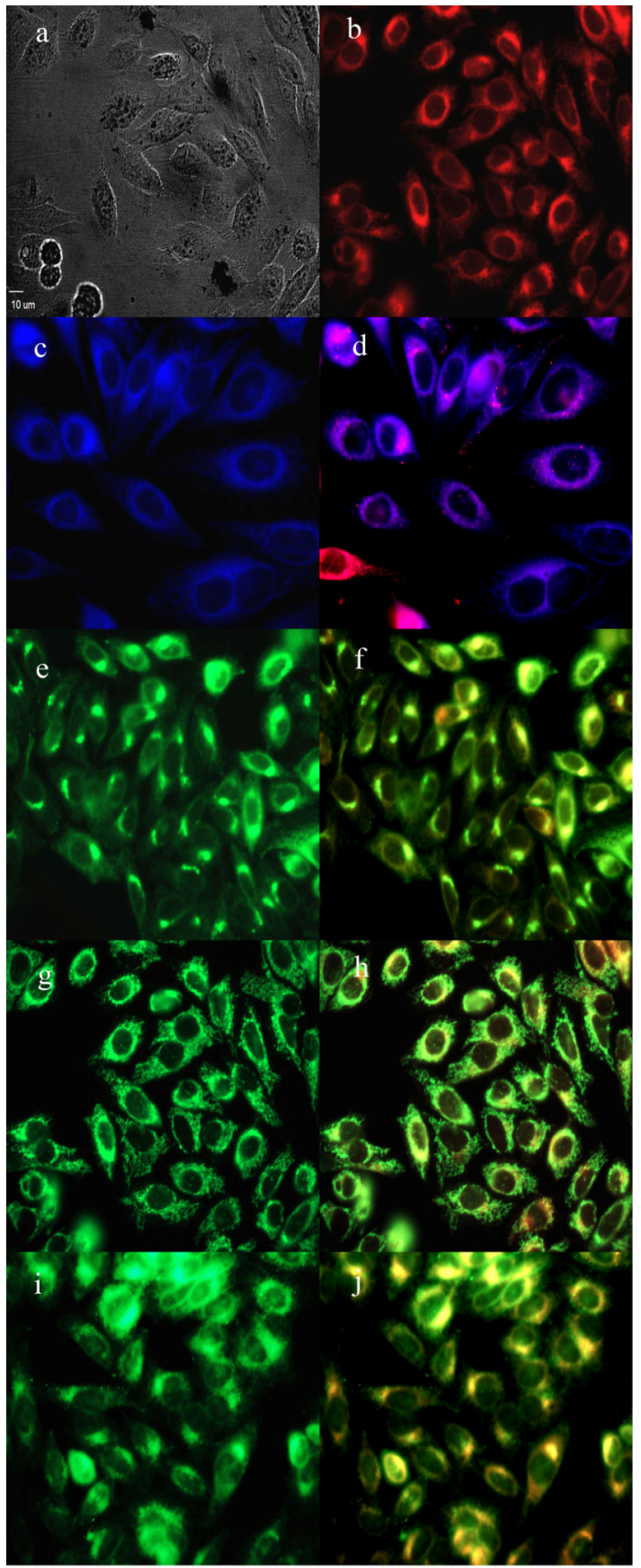

Figure 9.

Subcellular localization of BODIPY 2d in HEp2 cells at $10 \mu \mathrm{M}$ for $6 \mathrm{~h}$. a) Phase contrast, b) 2d fluorescence, c) ER tracker blue/white fluorescence, e) MitoTracker green fluorescence, g) BODIPY Ceramide, i) LysoSensor green fluorescence, and d), f), h), and j) overlays of organelle tracers with the BODIPY fluorescence. Scale bar: $10 \mu \mathrm{m}$. 


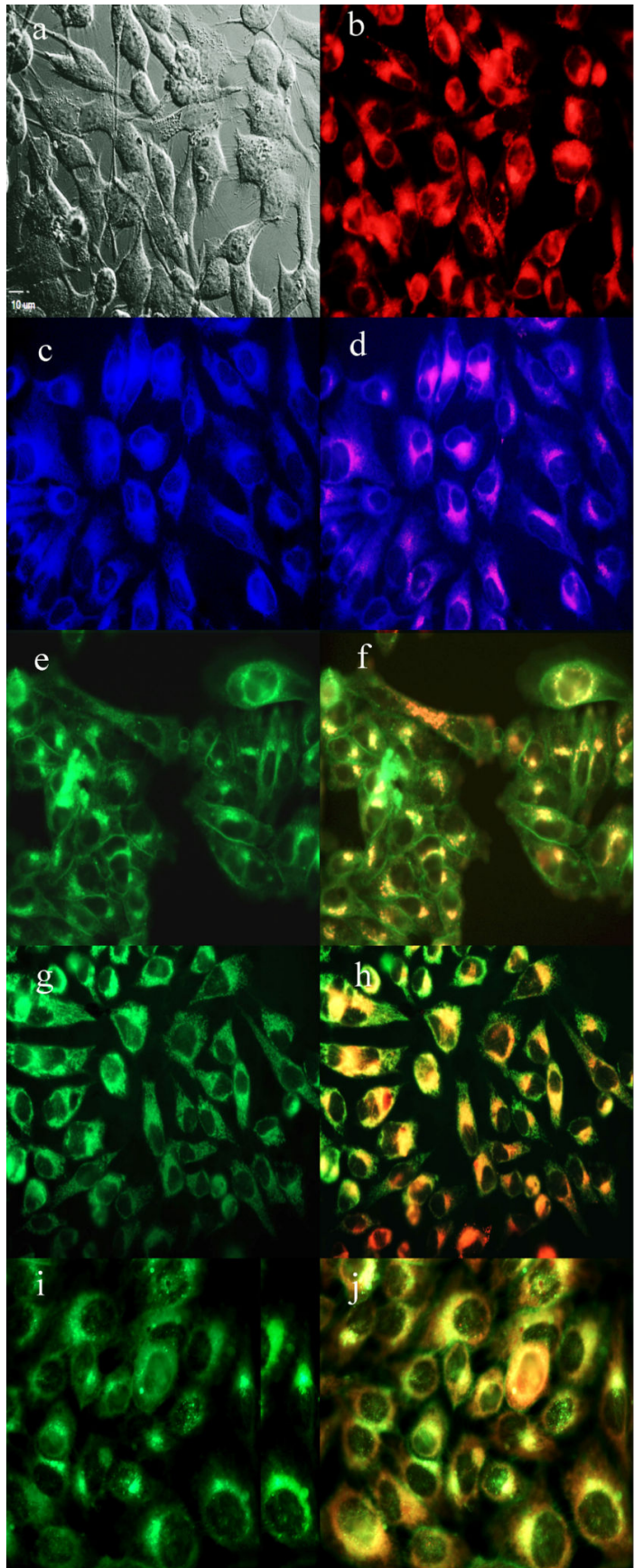

Figure 10.

Subcellular localization of BODIPY 2e in HEp2 cells at $10 \mu \mathrm{M}$ for $6 \mathrm{~h}$. a) Phase contrast, b) 2e fluorescence, c) ER tracker blue/white fluorescence, e) MitoTracker green fluorescence, g) BODIPY Ceramide, i) LysoSensor green fluorescence, and d), f), h), and j) overlays of organelle tracers with the BODIPY fluorescence. Scale bar: $10 \mu \mathrm{m}$. 

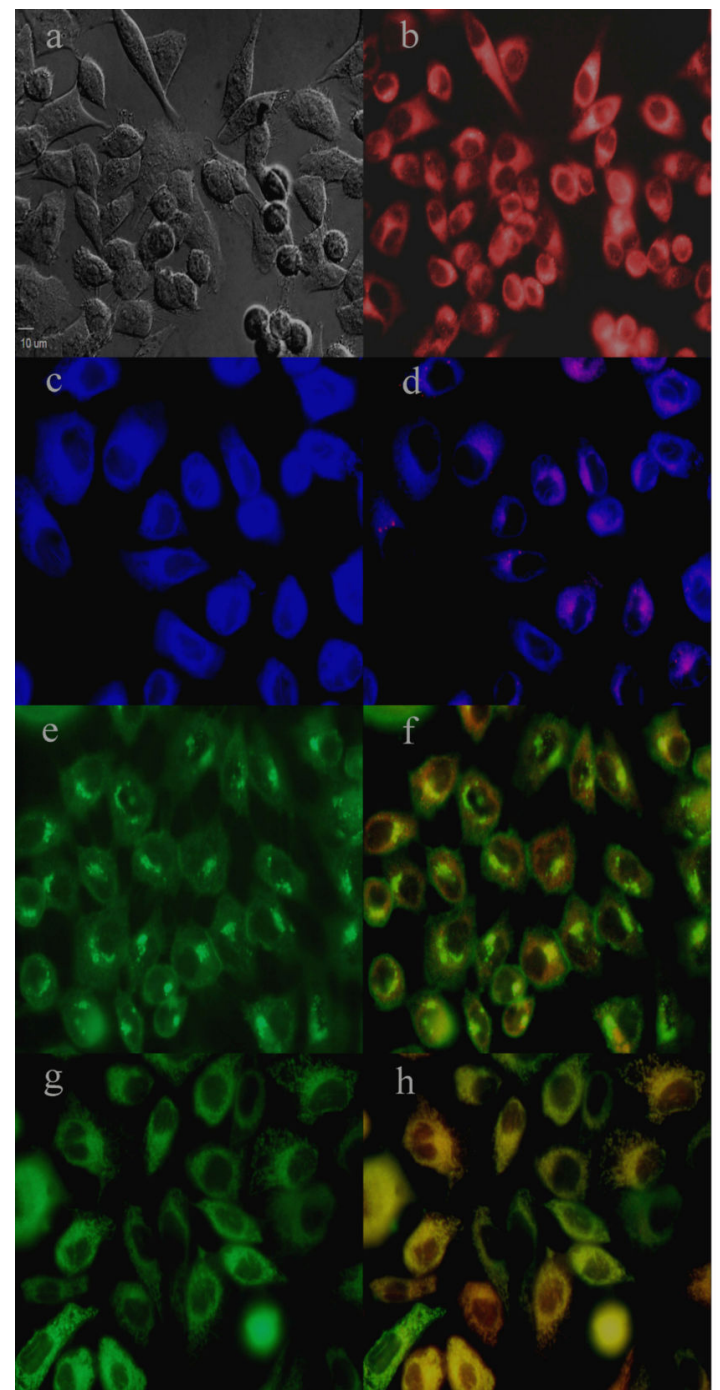

i
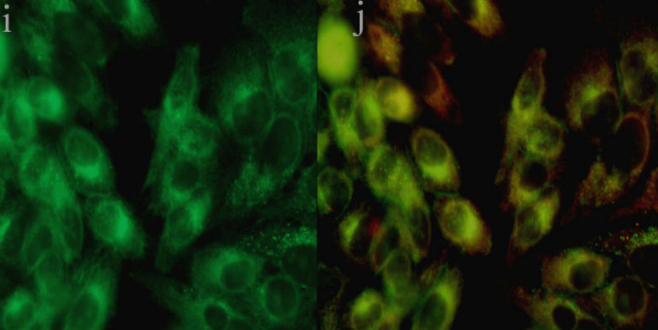

Figure 11.

Subcellular localization of BODIPY 3a in HEp2 cells at $10 \mu \mathrm{M}$ for $6 \mathrm{~h}$. a) Phase contrast, b) 3a fluorescence, c) ER tracker blue/white fluorescence, e) MitoTracker green fluorescence, g) BODIPY Ceramide, i) LysoSensor green fluorescence, and d), f), h), and j) overlays of organelle tracers with the BODIPY fluorescence. Scale bar: $10 \mu \mathrm{m}$. 
<smiles></smiles>

1

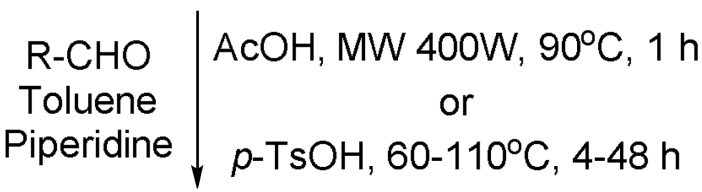<smiles></smiles><smiles></smiles><smiles>[Y]c1c[nH]c2ccccc12</smiles>

a<smiles>COCCOc1ccc(C)cc1</smiles>

b

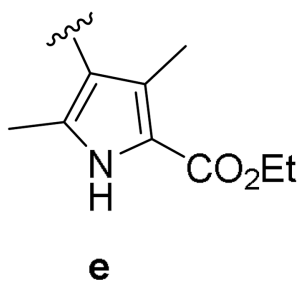

Scheme 1.

Knoevenagel condensations of BODIPY 1 with aryl aldehydes. 


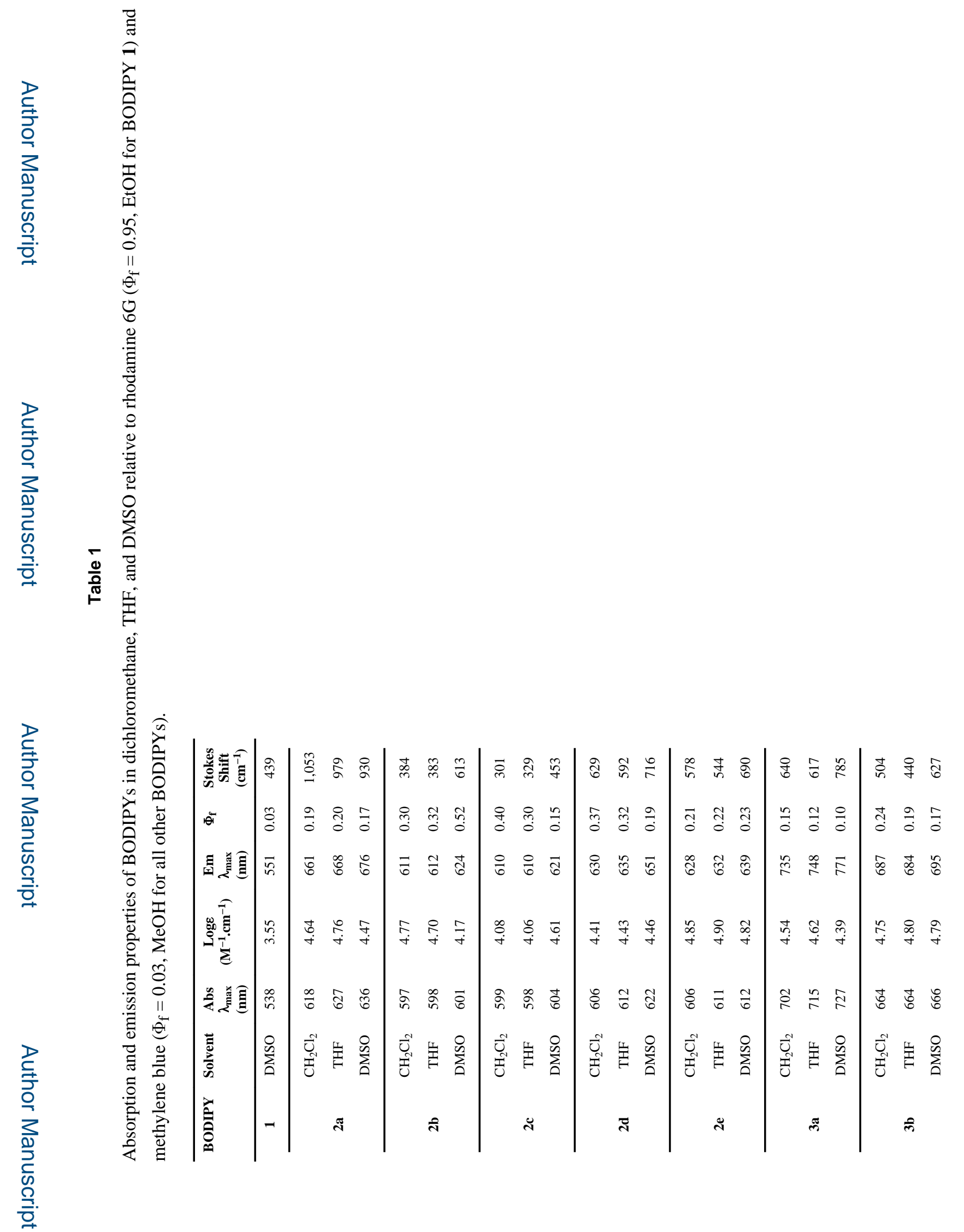




\section{Table 2}

Cytotoxicity (CellTiter Blue assay, $1.5 \mathrm{~J} / \mathrm{cm}^{2}$ ), comparative singlet oxygen quantum yields (relative to methylene blue) and partition coefficients in octanol-HEPES buffer $(\log P)$ of BODIPYs.

\begin{tabular}{ccccc}
\hline BODIPY & $\begin{array}{c}\text { Dark toxicity } \\
\left(\mathbf{I C}_{\mathbf{5 0}}, \boldsymbol{\mu M}\right)\end{array}$ & $\begin{array}{c}\text { Phototoxicity } \\
\left(\mathbf{I C}_{\mathbf{5 0}}, \boldsymbol{\mu M}\right)\end{array}$ & $\Phi_{\boldsymbol{\Delta}}$ & $\mathbf{L o g} \boldsymbol{P}$ \\
\hline $\mathbf{2 a}$ & 148 & 2.0 & 0.72 & 1.04 \\
$\mathbf{2 b}$ & $>400$ & 3.8 & 0.78 & 0.72 \\
$\mathbf{2 c}$ & $>400$ & 14.5 & 0.63 & 0.73 \\
$\mathbf{2 d}$ & $>400$ & 5.0 & 0.55 & 1.50 \\
$\mathbf{2 e}$ & $>400$ & 4.0 & 0.65 & 1.10 \\
$\mathbf{3 a}$ & $>400$ & $>100$ & 0.64 & 1.16 \\
$\mathbf{3 b}$ & $>400$ & $>100$ & 0.65 & 0.89 \\
$\mathbf{3 c}$ & $>400$ & $>100$ & 0.37 & 1.01 \\
$\mathbf{3 d}$ & $>400$ & $>100$ & 0.34 & 1.94 \\
$\mathbf{3 e}$ & $>400$ & $>100$ & 0.43 & 1.88 \\
\hline
\end{tabular}

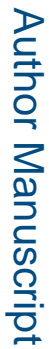

J Photochem Photobiol B. Author manuscript; available in PMC 2016 April 01. 